\title{
Manganese, iron and phosphorus cycling in an estuarine mudflat, Loire, France
}

\author{
Thibault De Chanvalon A. ${ }^{1,2,{ }^{*}}$, Mouret A. ${ }^{1}$, Knoery Joel ${ }^{2}$, Geslin E. ${ }^{1}$, Péron O. ${ }^{3}$, Metzger E. ${ }^{1}$ \\ ${ }^{1}$ LPG-BIAF, Université d'Angers, Université de Nantes, UMR CNRS 6112, 49045 Angers Cedex, \\ ${ }^{2}$ LBCM, Ifremer, Rue de I'lle d'Yeu, 44300 Nantes, France \\ ${ }^{3}$ Laboratoire Subatech, Groupe Radiochimie, IN2P3/CNRS/EMN/Université de Nantes, 4, rue Alfred \\ Kastler, BPe 20722, 44307 Nantes cedex 3, France
} France

* Corresponding author : A. Thibault de Chanvalon, email address : athibaultdc@gmail.com

\begin{abstract}
:
The sampling of surface sediment from two sites of a mudflat of the Loire Estuary during four contrasting seasons has led to new information about geochemical cycling under transient diagenesis fuelled by flood deposition. Based on stocks of reactive iron-oxides and manganese-oxides (ascorbateextracted) and pore water concentrations, the progressive evolution of flood deposits is described. Three major steps are observed: at first, there is no manganese, iron and phosphorus release into pore water within the flood-deposited layer. Then, during a period of approximately 1 month, Mn oxides are consumed while the dissolved Mn concentration increases. Simultaneously, the Fe oxide-rich layer from flood deposition prevents (or at least limits) phosphorus release into pore water as shown by the increasing $\mathrm{P} / \mathrm{Fe}$ ratio of the ascorbate extractions. During spring and summer, Fe oxides are reductively dissolved until complete depletion results. This period also corresponds to the saturation of Fe oxides by phosphorus and probably maximum $P$ release to the water column. The site located closer to the shore showed higher density of benthic faunas leading to more intense bioirrigation. The importance of bioturbation on the year scale for biogeochemical processes is discussed according to both bioirrigation and biomixing processes.
\end{abstract}

\section{Highlights}

- Flood deposition fuels a $>4$ month period of transient geochemical conditions involving sedimentary $\mathrm{Mn}, \mathrm{Fe}$ and $\mathrm{P}$. A sequential exhaustion of $\mathrm{Mn}$ and $\mathrm{Fe}$ reactive oxides due to diagenetic processes occurs at yearly average rates of $30 \mu \mathrm{mol} \mathrm{m}^{-2} \mathrm{~d}^{-1}$ and $170 \mu \mathrm{mol} \mathrm{m} \mathrm{m}^{-2} \mathrm{~d}^{-1}$, respectively. $\square$ These reactions control phosphorus release towards water column.

Keywords : Flood deposition, Ascorbat extraction, Transient diagenesis, Savitzky Golay Filter, RiOMars 


\section{Introduction}

The transport of particles from rivers to oceans occurs simultaneously with $\mathrm{Fe}$ and $\mathrm{Mn}$ oxide impoverishment (Poulton and Raiswell, 2002). Pioneer studies indicating these oxide losses focussed on estuaries (Moore et al., 1979) and deltas (Trefry and Presley, 1982) and underlined the potential role of early diagenesis for metal remobilization. Since these early studies, remobilization under suboxic conditions has been proposed to cover most muddy river-dominated oceanic margins (RiOMar, Aller et al., 2004; McKee et al., 2004; Roy et al., 2013) with different intensities according to site-specific sedimentary dynamics (Aller, 2004). However, due to frequent remobilization of muddy sediments (McKee et al., 2004), the wellknown vertical diagenetic sequence (Froelich et al., 1979) is also expected to occur temporally once the oxygen supply stops, e.g. after deposition (Aller, 2004; Sundby, 2006). As each oxidant is consumed on different time scales, one complexity of RiOMar environments is to capture transient states of diagenesis with a time series at the appropriate frequency. Previous studies report time scales of hours for oxygen, days to weeks for nitrate and months to years for Mn and Fe oxide consumption (Abril et al., 2000, 1999; Aller, 2004; Aller and Blair, 2006; Audry et al., 2006; Robert et al., 2004).

Because $\mathrm{Mn}$ and Fe oxide consumption occurs over months to years, the transient diagenesis signature would probably interfere with seasonal changes of environmental parameters. To date, most time series on a yearly scale on muddy sediments have explained variations of diagenesis as a steady state with changing environmental conditions. Thamdrup et al. (1994) invoked high productivity and increasing temperature to explain the collapse of Mn oxide stocks, while Rozan et al. (2002) described the transformation from Fe reactive oxide to the $\mathrm{FeS} / \mathrm{FeS}_{2}$ form by the increase of sulphate reduction with temperature. A last parameter, the importance of riverine reactive Fe oxide deposition, has been invoked by Meiggs and Taillefert (2011) to explain a time series dataset in which salinity increases 
without the simultaneous increase in sulphate reduction. Furthermore, numerous studies have described the seasonal variation of diagenesis intensity based on integrative indicators or on dissolved dataset only (Alperin et al., 1994; Beck et al., 2008; Cathalot et al., 2010; Dang et al., 2015; Deborde et al., 2008; Dellwig et al., 2007; Magni and Montani, 2006; Mortimer et al., 1999) and have also explained the observed temporal variability with the concept of steady state diagenesis, which varies with environmental parameters. However, on longer time scales, transient diagenesis is more often invoked. Transient diagenesis has been described by Deflandre et al. (2002) during a 2-year, yearly survey after a massive deposition in the Saguenay Fjord (Quebec), and it is frequently proposed to explain punctual sampling when a discrepancy between pore water and solid concentrations is observed (Alongi et al., 1996; Gobeil et al., 1997; Mackin et al., 1988; Pedersen et al., 1986).

In the Loire Estuary, winter flood pushes particles stored in the upstream Estuary towards the downstream Les Brillantes mudflat (network SYVEL, GIP Loire Estuaire) and enriches the mudflat in Mn and Fe oxides. This dynamics induces a large increase in $\mathrm{Mn}$ and Fe oxide stocks during winter, creating conditions that are likely to fuel transient diagenesis over months. The goal of this study is: (1) to investigate the validity of this scenario and its repeatability over different years by sampling $\mathrm{Mn}$ and Fe reactive oxides and pore water of the sediment in 4 contrasting hydrological seasons; (2) to understand the impact of different bioturbation regimes ; (3) to illustrate the impact of Fe cycling on phosphorus, a key nutrient that is often limiting in estuarine ecosystems (Anschutz et al., 1998; Meybeck et al., 1988; Rehm, 1985; Sundby et al., 1992). 


\section{Materials and methods}

\subsection{Study site}

The Loire River drains a basin with an area of $117,045 \mathrm{~km}^{2}$. The mean discharge is $890 \mathrm{~m}^{3}$ $\mathrm{s}^{-1}$ (range from $5200 \mathrm{~m}^{3} \mathrm{~s}^{-1}$ to $120 \mathrm{~m}^{3} \mathrm{~s}^{-1}$ ). The Loire Estuary is hyper-synchronous: the estuary shows an increasing tidal range upstream (Le Foch, 1961), reaching a maximum tidal range of approximately $7 \mathrm{~m}$. The daily surface salinity change is approximately 20 (network SYVEL, GIP Loire Estuaire) in the dredged channel in front of the study sites. Site $1\left(47^{\circ} 16^{\prime} 56.00 " \mathrm{~N}\right.$; $2^{\circ} 3^{\prime} 47.00^{\prime \prime W}$; Fig. 1) is located on the unvegetated part of Les Brillantes mudflat (largest mudflat of the Loire Estuary; 1350 ha), below the Mean High Water Neap Tide (MHWNT)

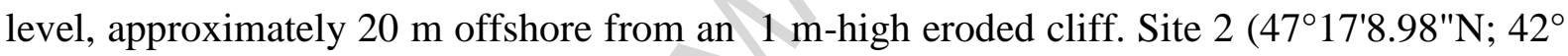
3'49.65"W; Fig. 1) is located approximately $500 \mathrm{~m}$ offshore. The differences between the two stations rely on the longer emersion time of site 1 , which hosts more macrofauna and diatoms than site 2 (Métais et al., pers. comm.; Benyoucef, 2014) and is composed of slightly finer sediment (Benyoucef, 2014).

\subsection{Sampling strategy}

Sampling was performed during four contrasting seasons (Fig. 1): in September 2012, the discharge was low (200 $\mathrm{m}^{3} \mathrm{~s}^{-1}$ at Nantes, DREAL-Pays-de-Loire, 2015), water temperature was $17^{\circ} \mathrm{C}$ and sediment pore water salinity was 16 ; in the beginning of May 2013, at the end of the flood period (discharge between 900 and $1800 \mathrm{~m}^{3} \mathrm{~s}^{-1}$ ), there was a water temperature of $13^{\circ} \mathrm{C}$ and a sediment salinity of 7 , and in February 2014 , during a major flood $\left(2400 \mathrm{~m}^{3} \mathrm{~s}^{-1}\right)$, there was a low water temperature $\left(7^{\circ} \mathrm{C}\right.$ ), strong wind (gusts up to $100 \mathrm{~km} \mathrm{~h}^{-1}$ ), salinity of 3 , and maximal tidal range. In April 2015, a weekly survey was performed at site 1 for one month while the flow continuously decreased. When temporally compared to the last high flood events (Fig. 1), the February campaign occurred during a flood event; the April time 
series was sampled between 1 and 2 months after the last high flood event, the May campaign 75 days after the last high flood event, and finally, the September campaign was performed 135 days after the last high flood event.

\subsection{Solid extraction and analyses}

For the first 3 campaigns, at each site, three cores (internal diameter $=8.2 \mathrm{~cm}$ ) were sampled during low tide and were brought back to the laboratory within $30 \mathrm{~min}$ after sampling and held at in situ temperature. After a few hours, the first core was sub-sampled (internal diameter $=3 \mathrm{~cm}$ ), sliced, weighed, and frozen for solid phase analyses. Within one week, samples were freeze-dried, weighed again to calculate the porosity and manually ground using an agate mortar. One aliquot $(\sim 2 \mathrm{mg})$ of this powder was used for organic carbon analysis on a EA1110 CHN/S/O (Thermo Fisher) after a 1 h-extraction in an atmosphere saturated with $\mathrm{HCl}$. Each chromatogram was inspected visually. Accuracy was verified with standards; the uncertainty was $4.5 \%$. A second aliquot ( $100 \mathrm{mg})$ was used for the extraction of reactive manganese, iron, and associated phosphate. Aliquots were exposed to $10 \mathrm{~mL}$ of a solution of ascorbic acid (buffered at $\mathrm{pH}$ 8) over 24 hours (Anschutz et al., 1998; Hyacinthe et al., 2001; Kostka and Luther, 1994) to the extract amorphous Fe(III) that is available for Fe-reducer microorganisms (Hyacinthe et al., 2006) as well as the reactive Mn(III) and Mn(IV) oxides (Anschutz et al., 2005) and associated phosphorus.

\subsection{Pore water analyses}

In each of the two remaining cores, one 1D DET probe (adapted from Davison and Zhang, 1994; Krom et al., 1994) was deployed for one night. Each DET probe is a perpex support containing 75 drilled cells that correspond to approximately $25 \mu \mathrm{L}$, allowing a vertical resolution of $2 \mathrm{~mm}$. Each cell was filled with agarose $(1.5 \% \mathrm{w} / \mathrm{w})$ and protected by a PVDF hydrophilic membrane $(0.2-\mu \mathrm{m}$ size pore, Millipore $\mathbb{C})$. Each probe was prepared the week 
before deployment, conserved in a wet clean plastic bag and bubbled with $\mathrm{N}_{2}$ for $6 \mathrm{~h}$ before deployment. During the deployment, the agarose gel equilibrated by diffusion with pore water. After retrieval, each agarose cell from the two probes was eluted in $5 \mathrm{~mL} \mathrm{HNO}_{3}(0.01$ mol L ${ }^{-1}$; Suprapur@ Merck) and further analysed by ICP-AES (Thermo Scientific iCAP 6300 Radial) to measure dissolved iron, manganese and phosphorus (uncertainty is $<5 \%$ for $\mathrm{Mn}$ and $\mathrm{Fe}$ and $25 \%$ for $\mathrm{P}$ ). This technique allows for the sampling dissolved species at a 200fold dilution according to a vertical resolution of $2 \mathrm{~mm}$ over a $2-\mathrm{cm}$ width window. Two others (1D DETs) were deployed in situ and dedicated to alkalinity measurement following the one-step method of Podda and Michard (1994) as adapted by Sarazin et al. (1999) for saline water and by Metzger et al. (2013) for 1D DET.

For the April 2015 survey, one core was sampled each week $\left(t_{0}-t_{1}-t_{2}-t_{3}\right)$ and sliced under an anoxic atmosphere. Pore water was extracted by centrifugation, acidified with $\mathrm{HNO}_{3}$ and analysed by ICP-AES as previously described. The sediment (not available for $\mathrm{t}_{0}$ ) was weighed, freeze-dried, ground and analysed as previously described for porosity and solid phase analyses.

\section{$2.5{ }^{210} \mathrm{~Pb}$ counting}

During the February campaign, a supplementary core was sampled for ${ }^{210} \mathrm{~Pb}$ analyses at station 1. Core sections ( $2 \mathrm{~cm}$ thick) were stored in double-sealed polyethylene bags and were immediately refrigerated until transportation to the laboratory, where they were frozen at $28^{\circ} \mathrm{C}$ and then freeze-dried and sieved at $2 \mathrm{~mm}$. The sedimentation rate was based on the determination of the excess or unsupported activity of ${ }^{210} \mathrm{~Pb}\left({ }^{210} \mathrm{~Pb}_{\mathrm{xs}}\right)$, which is incorporated rapidly into the sediment from atmospheric fallout and water column scavenging (Appleby and Oldfield, 1992). ${ }^{210} \mathrm{~Pb}_{\mathrm{xs}}$ was calculated as the difference between measured ${ }^{210} \mathrm{~Pb}$ (supported + excess) and ${ }^{226} \mathrm{Ra}$ and supported ${ }^{210} \mathrm{~Pb}$ and ${ }^{226} \mathrm{Ra}$, which were in secular 
equilibrium. Measurements were performed using a gamma spectrometer (Ortec ${ }^{\circledR} \mathrm{HPGe}$ GMX30P4-RB coaxial photon detector). The age of each sediment sample was estimated directly from the exponential radioactive decay of ${ }^{210} \mathrm{~Pb}\left(\lambda=0.0311 \mathrm{yr}^{-1}\right.$; (Turner and Delorme, 1996)). This approach does not require any hypothesis for the sedimentation rate, which would be complicated in such a dynamic environment.

\subsection{Production rate and stock calculations}

The production rates were determined from pore water profiles using the Savitzky Golay Filter (SGF; Meysman and Burdorf, in prep; Savitzky and Golay, 1964). The procedure is based on the polynomial interpolation of data by the SGF, resulting in the replacement of each data point by a polynomial function of a degree of three that best fits the actual point and its $n$ neighbours. As $n$ increases, more data points are considered for each polynomial calculation and more the noise is smoothed. Thus, the best compromise between smoothing and loss of information is evaluated using fractal analysis (Gneiting et al., 2012; Meysman and Burdorf, in prep.). The production rate $\mathrm{R}(\mathrm{z})$ is calculated using the first and the second derivatives of the polynomial at each point (Meysman and Burdorf, in prep.; Thibault de Chanvalon et al., in press), the porosity profiles ( $\phi$ fitted with an exponential function) and the temperature (assumed constant with depth).

$$
\mathrm{R}(\mathrm{z})=\left[-\phi \mathrm{D}_{\mathrm{s}} \frac{\partial^{2} \mathrm{C}}{\partial \mathrm{z}^{2}}-\left(\phi \frac{\partial \mathrm{D}_{\mathrm{s}}}{\partial \mathrm{z}}+\mathrm{D}_{\mathrm{s}} \frac{\partial \Phi}{\partial \mathrm{z}}\right) \cdot \frac{\partial \mathrm{C}}{\partial \mathrm{z}}\right]
$$

where $\mathrm{C}$ is the concentration of either $\mathrm{Mn}, \mathrm{Fe}$ or $\mathrm{P}$ and $\mathrm{Ds}$ is the effective diffusion coefficient $\mathrm{D}_{\mathrm{s}}=D_{m o l} / \theta^{2}$, where the molecular diffusion coefficient $D_{m o l}$ is calculated as an empirical function of the temperature and salinity (Boudreau, 1997). The tortuosity $\theta^{2}$ is typically taken as a function of porosity, as in the modified Weissberg relationship, $\theta^{2}=1-2$ $\ln (\Phi)$. The upper condition was defined as a production at the water sediment interface of 
zero. The SGF procedure was performed on the 15 dissolved profiles for $\mathrm{Mn}, \mathrm{Fe}$ and $\mathrm{P}$, as illustrated in Fig. 3.

The apparent production rate (APR) was calculated as the sum of the estimated positive production along the entire profile. APR represents the dissolution rate along the sediment column and thus quantifies the short term transformation rate of the reactive oxides. However, the APR calculation was based on four important assumptions: (1) the steady state of diagenesis reactions, (2) the absence of advection, (3) the occurrence of only negligible lateral exchanges and (4) the absence of solute exchange at a lower scale than the sampling resolution (no cryptic cycling). The validity and consequences of these assumptions have been abundantly discussed elsewhere (Berner, 1980; Boudreau, 1997; Thibault de Chanvalon et al., in press) and limit the use of APR to a relative indicator of the diagenesis intensity (i.e., efficient only to make paired comparisons). The uncertainty is calculated as the standard deviation of 6 results from different modelling studies, considering an uncertainty of $\pm 1 n$ for the window size and variability between the 2 replicates.

Stocks of reactive $\mathrm{Fe}$ and $\mathrm{Mn}$ oxides and associated $\mathrm{P}\left(\mathrm{st}\left(\mathrm{Fe}_{\mathrm{asc}}\right), \operatorname{st}\left(\mathrm{Mn}_{\mathrm{asc}}\right)\right.$ and $\left.\operatorname{st}(\mathrm{P})\right)$, respectively, in $\mathrm{mmol} \mathrm{m}^{-2}$ ) were calculated according to:

$$
\operatorname{st}\left(\mathrm{Fe}_{\mathrm{asc}}\right)=\sum_{l=1}^{l=l_{\max }}\left([\mathrm{Fe}]_{\mathrm{asc}}^{l}-[\mathrm{Fe}]_{\mathrm{asc}}^{l_{\max }}\right)(1-\phi) \rho \mathrm{h}_{l}
$$

where $[\mathrm{Fe}]_{\text {asc }}^{l}$ is the concentration of reactive Fe oxides of the layer $l, \rho$ is the density of dry sediment (supposedly 2.6), $\mathrm{h}_{l}$ is the width of the layer $l$ and $l_{\max }$ is the deeper layer, where the profile of reactive oxides reaches a minimal constant value. 


\section{Results}

\subsection{Integrative physical and chemical parameters}

The total organic carbon $\left(\mathrm{C}_{\text {org }}\right.$; Fig. 4$)$ ranges from $3.5 \mathrm{mmol} \mathrm{g}^{-1}(4.2 \%)$ at the surface to 1.5 mmol g${ }^{-1}(1.8 \%)$ at depth. The surface $\mathrm{C}_{\text {org }}$ content depends on the season (February > May > September). At site 1 in February and May, a local minimum is observed $(\mathrm{z}=2 \mathrm{~cm})$. These $\mathrm{C}_{\text {org }}$ depleted layers correspond to porosity minima. Despite these minima most porosity profiles decrease from 0.93 at the surface to 0.75 at core bottoms. In September, porosity profiles show for both sites, layers with rather constant values $1 \mathrm{~cm}$ below the sediment water interface (SWI) which are 6 and $2 \mathrm{~cm}$-thick for sites 1 and 2 respectively. The surface alkalinity has a strong temporal variability at site 1 from $2.5 \mathrm{mmol} \mathrm{L}^{-1}$ in May to $6.1 \mathrm{mmol} \mathrm{L}^{-1}$ in September while at site 2 alkalinity remains around $3.5 \mathrm{mmol} \mathrm{L}^{-1}$. Alkalinity profiles (replicates are similar and not shown) present little depth variation in February and May, but a slight increase with depth in September. The ${ }^{210} \mathrm{~Pb}_{\mathrm{xs}}$ profile presents no significant variation in the top $8 \mathrm{~cm} .{ }^{210} \mathrm{~Pb}_{\mathrm{xs}}$ decreases from 50 to $15 \mathrm{mBq} \mathrm{g}^{-1}$ at a depth of $14 \mathrm{~cm}$, suggesting a sedimentation rate of approximately $0.16 \mathrm{~cm} \mathrm{yr}^{-1}$.

\subsection{Mn, Fe and $P$ distribution over 3 years}

Figure 5 presents the profiles of dissolved and ascorbate-extracted $\mathrm{Fe}, \mathrm{Mn}$ and $\mathrm{P}$ from September 2012, May 2013, February 2014 and the last sampling $\left(t_{3}\right)$ of April 2015. Reactive Mn oxides show a constant concentration below a depth of $10 \mathrm{~cm}\left([\mathrm{Mn}]_{\mathrm{asc}}=4.5 \pm 1.5\right)$. Above $10 \mathrm{~cm}$, the $\mathrm{Mn}_{\text {asc }}$ profile is composed of: (1) an extremely sharp decrease of approximately $6 \pm 3 \mu \mathrm{mol} \mathrm{g}{ }^{-1}$ within the first $0.5 \mathrm{~cm}$ depth and (2) a smooth decrease, where the depth varies according to the season (February > April > May) and which is not observed in September. The dissolved $\mathrm{Mn}\left(\mathrm{Mn}_{\mathrm{d}}\right)$ profiles have bell-shaped patterns with maxima matching the depth of the $2^{\text {nd }} \mathrm{Mn}_{\text {asc }}$ gradient (see above) and maximum concentrations 
varying according to the season (April $>$ February $>$ May $\sim$ September). This feature is not observed for February at site 2.

The reactive iron oxide concentration (Fig. 5) decreases with depth. Minima of $[\mathrm{Fe}]_{\text {asc }}$ are reached at depths that vary according to the season (February $>$ April $\sim$ May $>$ September). Minimum values are between $[\mathrm{Fe}]_{\mathrm{asc}}=40 \mu \mathrm{mol} \mathrm{g} \mathrm{g}^{-1}$ and $60 \mu \mathrm{mol} \mathrm{g}$. For February and April samples, the depth of the $\mathrm{Fe}_{\text {asc }}$ decrease matches the $2^{\text {nd }} \mathrm{Mn}_{\text {asc }}$ gradient (see above) at both sites and occurs simultaneously with the $\mathrm{Fe}_{\mathrm{d}}$ maximum at site 1 (Fig. 5). In May and September, at site $1,[\mathrm{Fe}]_{\mathrm{d}}$ presents numerous maxima at depths between 2 and $7 \mathrm{~cm}$ $\left(\max [\mathrm{Fe}]_{\mathrm{d}} \sim 300 \mu \mathrm{mol} \mathrm{L} \mathrm{L}^{-1}\right.$ for both campaigns). Site 2 has a lower constant concentration excepted for May, when a very narrow peak is observed at a depth of $1 \mathrm{~cm}$ (also visible on the replicate).

Fe-bound phosphorus (extracted by ascorbate) has a pattern similar to $\mathrm{Fe}_{\text {asc }}$ (Fig. 5), with concentrations ranging from $[\mathrm{P}]_{\mathrm{asc}}=6$ to $[\mathrm{P}]_{\mathrm{asc}}=22 \mu \mathrm{mol} \mathrm{g}{ }^{-1}$. However, the $\mathrm{P}_{\text {asc }}$ profiles differ from those of $\mathrm{Fe}_{\text {asc }}$ according to a systematic increase in the top $2 \mathrm{~cm}$. Furthermore, in the first $10 \mathrm{~cm},[\mathrm{P}]_{\mathrm{d}}$ follows the $[\mathrm{Fe}]_{\mathrm{d}}$ trend, but is characterized deeper in the sediment by a regular increase at site 1 (mostly visible in the April profile).

\subsection{Mn, Fe and P during the April survey}

Figure 6 shows the evolution of extracted and dissolved Mn, Fe and P during the weekly survey of April 2015. $\mathrm{Mn}_{\mathrm{d}}$ and $\mathrm{Fe}_{\mathrm{d}}$ show a peak that reaches its maximum at $\mathrm{t}_{2}$, with concentrations of approximately 250 and $180 \mu \mathrm{mol} \mathrm{L} \mathrm{L}^{-1}$, respectively. At $\mathrm{t}_{0},[\mathrm{Mn}]_{\mathrm{d}}$ and $[\mathrm{Fe}]_{\mathrm{d}}$ are almost constant $\left(\sim 25 \mu \mathrm{mol} \mathrm{L} \mathrm{L}^{-1}\right.$ and below detection, respectively), and at $\mathrm{t}_{3}$, the peaks seem to shrink. Contrary to February 2014, May 2013 and September 2012, no peaks were observed for dissolved phosphorus during the weekly survey of April 2015. $[\mathrm{P}]_{\mathrm{d}}$ increases 
steadily with depth, reaching a maximum of approximately $\max [\mathrm{P}]_{\mathrm{d}}\left(\mathrm{t}_{3}\right)=180 \mu \mathrm{m} \mathrm{L}^{-1}$ at a depth of $20 \mathrm{~cm}$. The $[\mathrm{P}]_{\mathrm{d}}$ slopes follow the same dynamics as the peak intensities of metals.

\subsection{Overall transformation of reactive oxides stocks}

Table 1 shows the reactive oxide stocks calculated from ascorbate-extracted manganese and iron for both sites and sampling dates. The stocks of reactive Fe oxides ( $\mathrm{st}(\mathrm{Fe}))$ are 5 times higher than st(Mn) in February, only 2 times higher in May and September. Site 1 showed higher stocks than site 2 in February and May while stocks were roughly the same in September for both sites.

The apparent production rates (Fe-APR and Mn-APR; Table 2) have similar ranges from 0 mmol m $\mathrm{d}^{-1}$ in April $\mathrm{t}_{0}$, to $1.76 \pm 1.15 \mathrm{mmol} \mathrm{m}^{-2} \mathrm{~d}^{-1}$ in September for Fe-APR, and from 0.02 mmol m $\mathrm{m}^{-2}$ in April $\mathrm{t}_{0}$, to $1.43 \pm 0.58 \mathrm{mmol} \mathrm{m}^{-2} \mathrm{~d}^{-1}$ in April $\mathrm{t}_{2}$ for Mn-APR, at site 1 . However, the temporal distribution differs: higher values are observed in April $t_{2}$, May and September for Fe-APR, while the maxima correspond to the April $t_{1}, t_{2}$ and $t_{3}$ samples for Mn-APR. Site 1 has a 2 to 10 times higher APR than site 2 .

\section{Discussion}

\subsection{Flood deposition}

The constant ${ }^{210} \mathrm{~Pb}_{\mathrm{xs}}$ value in the top $8 \mathrm{~cm}$ observed in the core sampled at site 1 in February 2014 (Fig. 4) can be interpreted either as biomixing or as a recent deposition. However, February corresponds to the season with the lowest densities of macrofauna (Métais et al., pers. comm.). Important mean discharges $\left(2800 \mathrm{~m}^{3} \mathrm{~s}^{-1}\right)$ and strong winds have been observed before and during the February campaign (Fig. 1). According to these observations, the constant signal of ${ }^{210} \mathrm{~Pb}_{\mathrm{xs}}$ is probably due to a recent deposition event. Moreover, this 
scenario matches the high constant porosity layer (Fig. 4) enriched in $\mathrm{C}_{\text {org }}$ (Fig. 4), $\mathrm{Mn}_{\mathrm{asc}}, \mathrm{Fe}_{\mathrm{asc}}$ and $\mathrm{P}_{\text {asc }}$ (Fig. 5). The mudflat topography was not measured in our study, but deposition of a layer with a thickness of 5 to 10 -cm on mudflats has frequently been reported for the French Atlantic coast (Deloffre et al., 2006; Goubert et al., 2010). Finally, during flooding, the time series measurement of the Loire turbidity (SYVEL network) reports a movement of the suspended sediment stored in the estuary, from upstream to the Brillantes mudflat. No ${ }^{210} \mathrm{~Pb}$ data are available for site 2, but $\mathrm{C}_{\text {org }}$, porosity (Fig. 4), $\mathrm{Mn}_{\text {asc }}, \mathrm{Fe}_{\mathrm{asc}}$ and $\mathrm{P}_{\text {asc }}$ (Fig. 5) show a similar pattern up to a depth of $4 \mathrm{~cm}$, which indicates a recent, but thinner, flood deposition. 


\subsection{Transient diagenesis}

The description of transient diagenesis is based on samples from different years that are representative of contrasting seasons and are compared according to the delay between the sampling date and last flood. This procedure neglects the yearly variability of flood deposition and has been designed to identify processes with yearly cyclicity. Because $\mathrm{Fe}_{\text {asc }}$ corresponds to microbial reductible Fe oxides (Hyacinthe et al., 2006; Raiswell et al., 2010) and $\mathrm{Mn}_{\text {asc }}$ to reactive Mn oxides (Anschutz et al., 2005), the flood deposition identified in February represents an important stock of oxidants that are likely to fuel transient diagenesis for several months.

For a few days after the sedimentation event (February; Fig. 1), neither $[\mathrm{Mn}]_{\mathrm{d}}$ nor $[\mathrm{Fe}]_{\mathrm{d}}$ indicates metal recycling in the flood deposition (Fig. 5). However, $[\mathrm{Mn}]_{\mathrm{d}}$ or $[\mathrm{Fe}]_{\mathrm{d}}$ presents maxima at the interface with the older sediment, probably as relics of the pre-deposition steady state. This period corresponds to the delay for oxygen and nitrate to be consumed by respiration including the required succession of the microbial community (Aller, 2004), and by oxidation of reduced compounds diffusing from below. More precisely, the $\mathrm{Mn}_{\mathrm{d}}$ maximum is located slightly above the $\mathrm{Fe}_{\mathrm{d}}$ maximum (a depth of $6 \mathrm{~cm}$ versus $8 \mathrm{~cm}$, respectively), indicating the beginning of the consumption of most reactive $\mathrm{Mn}$ oxides by reduced compounds that diffuse upward.

Two to three months after deposition, the April time series and May campaign show an increase in Mn recycling, as indicated by the Mn-APR increase (Fig. 7). Once reductively dissolved, some ions could leave the sediment or re-precipitate in a non-ascorbate extractable mineralogical form such as $\mathrm{MnCO}_{3}$ or FeS (Aller, 2014; Robbins and Callender, 1975). As expected, a decrease in $\mathrm{Mn}_{\text {asc }}$ stocks occurs simultaneously with the increase in Mn-APR values (Fig. 7), and the $\mathrm{Mn}_{\text {asc }}$ profiles become characteristic of older deposition (Fig. 5): (1) 
the $2^{\text {nd }}[\mathrm{Mn}]_{\text {asc }}$ gradient is smoother due to the progressive dissolution of Mn oxides and (2) the produced $\mathrm{Mn}_{\mathrm{d}}$ that diffuses upward and precipitates in the oxic layer, which produces a sharp $\mathrm{Mn}_{\text {asc }}$ peak below the water-sediment interface (Aller, 1980; Murray and Irvine, 1895; Robbins and Callender, 1975; Sundby and Silverberg, 1985).

During this period, Fe-APR increases progressively from Fe-APR $\sim 0.7 \mathrm{mmol} \mathrm{m}^{-2} \mathrm{~d}^{-1}$ in April to Fe-APR $~ 1.2 \mathrm{mmol} \mathrm{m} \mathrm{m}^{-2}$ in May (Fig. 7), indicating a switch of the main oxidant from $\mathrm{Mn}$ oxides to Fe oxides, as predicted by the temporal succession of oxidants in transient diagenesis (Aller, 2004; Sundby, 2006). This increase in recycling intensity explains the roughly constant stock of $\mathrm{Fe}_{\text {asc }}$ in April and May, while the stock decreases between May and September (Fig. 7).

In conclusion, our results are in agreement with the cyclicity of transient diagenesis in the Les Brillantes mudflat. The temporal succession of oxidants is composed of an event of oxide-rich sedimentation during flooding (data from February 2014), followed by a progressive consumption of reactive oxide stocks (data from May and April) towards a steady state (data from September). Previous studies describing seasonal variations for coastal Mn and Fe cycles did not report transient diagenesis, but reported steady state diagenesis with changing environmental conditions (Meiggs and Taillefert, 2011; Rozan et al., 2002; Thamdrup et al., 1994). In the Les Brillantes mudflat, temperature and surface primary production appear to be secondary parameters controlling metal recycling during transient diagenesis. 


\subsection{Impact of fauna}

The main difference in reactive metal oxides between site 1 and site 2 at steady state (September data) is the $\mathrm{Fe}_{\text {asc }}$ increase in the top $2 \mathrm{~cm}$ at site 2 (Fig. 5), which is absent at site 1. Two environmental parameters also differ between the sites: (1) organic matter, which is more concentrated and labile at site 1 according to Fig. 4 and surface Chl-a concentrations (Meleder, pers. comm.), and (2) bioturbation intensity, which is more pronounced at site 1. Macrofauna is represented by contrasting communities with, in September, a dominance of Nereis diversicolor at site $1\left(\sim 200\right.$ ind $\left.\mathrm{m}^{-2}\right)$, which has a theoretical faster biomixing rate (Duport et al., 2006; Quintana et al., 2007) compared to the dominant species at site 2, which is Heteromastus filiformis ( 50 ind $\mathrm{m}^{-2}$; Métais, pers. comm.). Different bioturbation regimes are known to impact the vertical distribution of solids. At least two processes are likely to increase with bioturbation (Kristensen et al., 2012; Meysman et al., 2006): (1) biomixing, which would homogenize the solid phase and (2) bioirrigation, which would increase the exchange rate between sediment porewater and overlying water by ventilation of active burrows.

At site 2, steady state diagenesis occurs without major bioturbation interference: reduced $\mathrm{Fe}_{\mathrm{d}}$ diffuses upward and is oxidized by Mn-oxide, nitrate or oxygen in the top $\sim 2 \mathrm{~cm}$. Consequently, the resulting Fe $_{\text {asc }}$ profile has a marked surface maximum (Fig. 5, Sept., site 2). In a highly bioturbated environment, however, diffusive transport of $\mathrm{Fe}_{\mathrm{d}}$ becomes negligible due to the exchange generated by burrow ventilation events (Raiswell, 2011; Thibault de Chanvalon et al., 2016). These exchanges occur along ephemeral burrow walls that do not allow any visible oxide accumulation. Therefore, a high bioturbation short-circuits the preponderant role of the interface in water sediment exchanges, resulting in a constant $[\mathrm{Fe}]_{\text {asc }}$ profile (Fig. 5, site 1, September). However, the sharp $\mathrm{Mn}_{\text {asc }}$ surface gradient seems contradictory with a high biomixing rate, as a high biomixing rate would homogenize the 
sediment. This paradox can be solved by considering a bioturbation regime with low enough biomixing to permit the establishment of a $\mathrm{Mn}_{\text {asc }}$ gradient but with high enough bioirrigation to oxidize most of the $\mathrm{Fe}_{\mathrm{d}}$. In this case, as Mn oxidation is slower than iron oxidation and is not favourable because $[\mathrm{Fe}]_{\mathrm{d}}$ is present (e.g., Wang and Van Cappellen, 1996; Martin, 2003), deep oxidation processes such as bioirrigation seem more effective for iron while surface oxidation processes due to oxygen diffusion are more effective to oxidize manganese. 


\subsection{Yearly budget of reactive $\mathrm{Fe}, \mathrm{Mn}$}

The evolution of reactive oxide stocks depends on three main processes: erosion, burial, and biogeochemical reactions. Because the apparent production rate (APR) quantifies the dissolution of oxide stocks, the APR is expected to be the upper bound of the stock variation rate due to biogeochemical reactions. However, the APR is always below the average stock variation rate $\left(\max (\mathrm{Fe}-\mathrm{APR})=1.76 \mathrm{mmol} \mathrm{m}^{-2} \mathrm{~d}^{-1}\right.$ and $\max (\mathrm{Mn}-\mathrm{APR})=1.43 \mathrm{mmol} \mathrm{m} \mathrm{d}^{-2}$

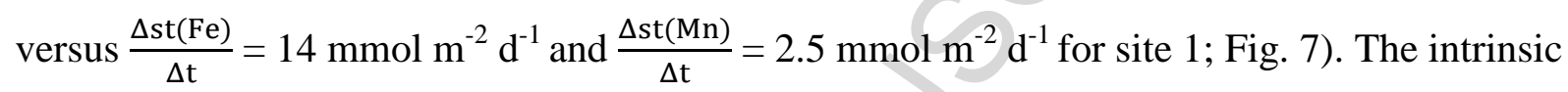
limitations of APR (see §2.6) can explain part of this offset, but most of the offset is probably due to erosion of the surface sediments (Deloffre et al., 2006; Goubert et al., 2010).

To quantify the erosive loss from the mudflat, a yearly averaged budget is performed. Assuming a yearly steady state, input and output fluxes can be equalized for both particles and ascorbate reactive iron. Thus:

$$
\begin{gathered}
J(F e)_{s e t}=J(F e)_{b}+J(F e)_{e}+J(F e)_{g} \\
J(\text { par })_{s e t}=J(\text { par })_{b}+J(\text { par })_{e}
\end{gathered}
$$

where $J(F e)_{\text {set }}$ is the flux of ascorbate reactive iron that settles (in $\left.\mathrm{mol} \mathrm{m}^{-2} \mathrm{~d}^{-1}\right)$ and $J(F e)_{b}$; $J(\mathrm{Fe})_{e}$, and $J(\mathrm{Fe})_{g}$ are the output fluxes of iron due to burial, erosion or geochemical reactions, respectively. $J(\text { par })_{s e t}, J(\text { par })_{b}, J(\text { par })_{e}$ represent similar fluxes for particles in $\mathrm{g}$ $\mathrm{m}^{-2} \mathrm{~d}^{-1}$. We assume that geochemical reactions do not alter the mass of particles (i.e., J(par $)_{g}$ is neglected). Combining these equations leads to:

$$
J(\text { par })_{\text {set }} \frac{J(F e)_{\text {set }}}{J(\text { par })_{\text {set }}}=J(\text { par })_{b} \frac{J(F e)_{b}}{J(\text { par })_{b}}+\left(J(\text { par })_{\text {set }}-J(\text { par })_{b}\right) \frac{J(F e)_{e}}{J(\text { par })_{e}}+J(F e)_{g}
$$

Then, if we assume that $J(F e)_{e} / J(\text { par })_{e}=J(F e)_{\text {set }} / J(\text { par })_{\text {set }}$, i.e., there is no chemical transformation before any erosion, equation (5) can be reorganized as: 


$$
J(F e)_{g}=J(\text { par })_{b}\left(\frac{J(F e)_{s e t}}{J(p a r)_{\text {set }}}-\frac{J(F e)_{b}}{J(\text { par })_{b}}\right)
$$

Therefore, the overall output flux (geochemical loss) of iron can be estimated as:

$$
J(F e)_{g}=J(\text { par })_{b}\left([\mathrm{Fe}]_{\mathrm{asc}}(\text { flood })-[\mathrm{Fe}]_{\mathrm{asc}}(\mathrm{z}=\infty)\right)
$$

where $J(\text { par })_{b}$ is the burial rate, which is estimated from the ${ }^{210} \mathrm{~Pb}$ profile $\left(1010 \mathrm{~g} \mathrm{~m}^{-2} \mathrm{yr}^{-}\right.$ $\left.{ }^{1}\right) ;[\mathrm{Fe}]_{\text {asc }}$ (flood) is the concentration of flood deposition (estimated from February as 103 $\left.\mu \mathrm{mol} \mathrm{g}^{-1}\right)$, and $[\mathrm{Fe}]_{\mathrm{asc}}(\mathrm{z}=\infty)$ is the concentration of the burial sediment $\left(40 \mu \mathrm{mol} \mathrm{g} \mathrm{g}^{-1}\right)$.

This estimation of geochemical loss is a minimum because it implicitly supposes that the eroded sediment is as oxide-rich as the deposited sediment, i.e., it neglects geochemical loss before sediment is eroded. A similar estimation is performed for $[\mathrm{Mn}]_{\text {asc }}$ and leads to a minimum averaged yearly loss of $J(F e)_{g}=170 \pm 60 \mu \mathrm{mol} \mathrm{m}^{-2} \mathrm{~d}^{-1}$ and $J(M n)_{g}=30 \pm 10 \mu \mathrm{mol}$ $\mathrm{m}^{-2} \mathrm{~d}^{-1}$. These values are in agreement with the mean APR $\left(\right.$ mean $(\mathrm{Fe}-\mathrm{APR})=930 \mu \mathrm{mol} \mathrm{m} \mathrm{d}^{-2}$ ${ }^{1}$ and mean $\left.(\mathrm{Mn}-\mathrm{APR})=350 \mu \mathrm{mol} \mathrm{m} \mathrm{m}^{-2} \mathrm{~d}^{-1}\right)$, as the APR is the upper bound of the stock variation rate due to geochemical reactions. These results indicate that on a yearly average, $18 \%$ of $\mathrm{Fe}$ and $8 \%$ of $\mathrm{Mn}$ of the dissolved oxides definitively leave the pool of reactive oxides. This budget also underlines the importance of erosive processes that are, at a maximum, responsible for $J(F e)_{e} / J(F e)_{\text {set }}=97 \%$ of the oxide stock variation in the Les Brillantes mudflat, whereas geochemical reactions are responsible for at least $1.8 \%$ of the stock loss and burial is responsible for $1.2 \%$ of the stock loss. 


\subsection{Phosphorus dynamics}

Dissolved phosphorus $\left(\mathrm{P}_{\mathrm{d}}\right)$ is produced in sediment by oxidation of organic matter and by desorption when Fe oxides are reductively dissolved. The general correlation between $[\mathrm{Fe}]_{\text {asc }}$ and $[\mathrm{P}]_{\text {asc }}\left(\mathrm{r}^{2}>0.6\right.$, Fig. 8$)$ confirms that $\mathrm{P}_{\text {asc }}$ is bound to Fe oxides. Moreover, the distribution between $[\mathrm{Fe}]_{\mathrm{d}}$ and $[\mathrm{P}]_{\mathrm{d}}$ (Figs. 5 and 6) and their correlation (Fig. 8c) indicate that Fe oxides are the main sources of $P_{d}$ in the top $10 \mathrm{~cm}$. However, in April 2015, [P] $]_{d}$ increases with depth independently from $[\mathrm{Fe}]_{\mathrm{d}}$ (Fig. 6), which demonstrates the increasing contribution of the organic $\mathrm{P}$ source from organic matter remineralization according to depth. This observation is in agreement with the 2D dataset (Thibault de Chanvalon et al., 2015) from the same site.

Figure 8a shows the seasonal pattern of $[\mathrm{P}]_{\mathrm{asc}} /[\mathrm{Fe}]_{\mathrm{asc}}\left(\right.$ from $[\mathrm{P}]_{\mathrm{asc}} /[\mathrm{Fe}]_{\mathrm{asc}} \sim 0.14$ in Feb. to $[\mathrm{P}]_{\mathrm{asc}} /[\mathrm{Fe}]_{\mathrm{asc}} \sim 0.2$ in May and Sept.), indicating the progressive $\mathrm{P}$ enrichment of Fe oxides after flood deposition until complete saturation occurs after May. Such ratio is higher than most of the values of sediment reported in the literature (Table 3). Although some cited studies have used different extraction schemes, these comparisons indicate a nearly complete saturation of Fe oxides in the Les Brillantes mudflat. The enrichment of $\mathrm{P}_{\text {asc }}$ occurs mostly in the top $2 \mathrm{~cm}$, indicating the more effective adsorption of $\mathrm{P}$ where Fe oxides are freshly precipitated and/or where there is a higher $\mathrm{P}$ supply due to intense organic matter remineralization. Therefore, during approximately 3 months, Fe oxides buffer phosphorus recycling (i.e., release towards water column) by trapping $\mathrm{P}_{\mathrm{d}}$ and therefore acting as an "iron curtain" (Mortimer, 1971). During spring, $[\mathrm{P}]_{\text {asd }} /[\mathrm{Fe}]_{\text {asc }}$ reaches a constant value indicating that Fe-oxides are saturated in phosphorus and probably stop buffering phosphorus release to the water column. As a consequence, dissolved phosphorus produced in the sediment from organic matter remineralisation freely diffuses towards the water column and may stimulate primary production during spring. Such scenario could explain recent hypoxia events despite 
an important decrease of phosphorus inputs from the watershed due to policy regulation since the 1990s (ECC, 1991; Minaudo et al., 2015).

The fact that $[\mathrm{P}]_{\mathrm{d}} /[\mathrm{Fe}]_{\mathrm{d}}$ and $[\mathrm{P}]_{\mathrm{asc}} /[\mathrm{Fe}]_{\text {asc }}$ have similar values of $\sim 0.2$ at the surface of most samples (Fig. 8c) confirms that dissolved species originate from reductive dissolution of $\mathrm{Fe}$ oxides. However, deeper in the sediment, especially in February (Site 1) and September (Site 1), $[\mathrm{P}]_{\mathrm{d}} /[\mathrm{Fe}]_{\mathrm{d}}$ increases, following trends which slopes are about 0.9 and 1.6 respectively (Fig. 8c). Such observations indicate that pore water is enriched in P compared to its source. This offset between $[\mathrm{P}]_{\mathrm{d}} /[\mathrm{Fe}]_{\mathrm{d}}$ and $[\mathrm{P}]_{\mathrm{asc}} /[\mathrm{Fe}]_{\mathrm{asc}}$ could be explained by (1) the existence of another reactive solid phase enriched in both $\mathrm{Fe}$ and $\mathrm{P}$ or by (2) a longer residence time of $\mathrm{P}_{\mathrm{d}}$ compared to $\mathrm{Fe}_{\mathrm{d}}$ due to adsorption kinetics of $\mathrm{P}$ on freshly precipitated Fe-oxides. Indeed, a factor 5 between residence times of $\mathrm{P}_{\mathrm{d}}$ and $\mathrm{Fe}_{\mathrm{d}}$ could explain the relative enrichment in $\mathrm{P}_{\mathrm{d}}$ despite similar production rates. This possibility is supported by the kinetics of $\mathrm{P}$ adsorption which occurs in few hours (Neupane et al., 2014) while Fe precipitation in oxic conditions occurs in few minutes (Millero et al., 1987). This scenario could explain offsets between $[\mathrm{P}]_{\mathrm{d}} /[\mathrm{Fe}]_{\mathrm{d}}$ and $[\mathrm{P}]_{\mathrm{asc}} /[\mathrm{Fe}]_{\text {asc }}$ observed in other coastal settings during spring and summer while Fe-oxide is the dominant source of dissolved phosphorus (Rozan et al. (2002); Deborde et al. (2008); Mort et al. (2010)). Moreover, in case of redox oscillations, the delay between Fe precipitation and $\mathrm{P}$ adsorption would favour $\mathrm{P}$ release towards the water column. This would be probably magnified in case of "fast" transport processes of solutes such as advection occurring during bioirrigation events as suggested in other environments rich in iron oxydes (e.g.: Clavero et al, 1991; Davenport et al., 2012; Ekeroth et al., 2012).

\section{Conclusions}

The Fe, Mn and P cycling in the Les Brillantes mudflat appears to be controlled by flood deposition events that bring oxide-rich sediments, fuelling transient diagenesis over several 
months. First, neither iron nor manganese is mobilized in the flood-deposited layer. Then, after approximately 1 month, Mn oxides are reductively dissolved while Fe oxides limit the phosphorus release by adsorption. Finally, the reductive dissolution of Fe oxide becomes more important, increasing Fe-oxide depletion and probably releasing dissolved iron and associated metals and nutrients to the overlying water. This geochemical cycle is typical of a low sulphate sediment that is undergoing sudden and limited deposition events. Furthermore, analyses at sites with contrasting bioturbation intensities show the importance of bioirrigation compared to biomixing for metal cycling. A similar approach must be extended to the subtidal estuarine sediment to better constrain the large scale heterogeneity of benthic fluxes, especially regarding the impact of dredging in the release of nutrients and therefore in the hypoxic events documented in the Loire Estuary.

\section{Acknowledgements}

This study is part of the RS2E - OSUNA project funded by the Région Pays de la Loire. Thanks to Cyrille Guindir, Clément Chauvin, Romain Levrard, Livia Defaye, Anthony Barbe and Eric Bénéteau for their technical help. A special thanks to the 2015 class of Geology (Licence) of the University of Angers that sampled and analyzed the first pore water profiles of the time series. The authors want to thank the associate editor and reviewers for their valuable suggestions to improve this manuscript. 


\section{Bibliography}

Abril, G., Etcheber, H., Le Hir, P., Bassoullet, P., Boutier, B., Frankignoulle, M., 1999. Oxic/anoxic oscillations and organic carbon mineralization in an estuarine maximum turbidity zone (The Gironde, France). Limnol. Oceanogr. 44, 1304-1315. doi:10.4319/lo.1999.44.5.1304

Abril, G., Riou, S.A., Etcheber, H., Frankignoulle, M., de Wit, R., Middelburg, J.J., 2000. Transient, Tidal Time-scale, Nitrogen Transformations in an Estuarine Turbidity Maximum-Fluid Mud System (The Gironde, South-west France). Estuar. Coast. Shelf Sci. 50, 703-715. doi:10.1006/ecss.1999.0598

Aller, R.C., 2014. 8.11 - Sedimentary Diagenesis, Depositional Environments, and Benthic Fluxes, in: Turekian, H.D.H.K. (Ed.), Treatise on Geochemistry (Second Edition). Elsevier, Oxford, pp. 293-334.

Aller, R.C., 2004. Conceptual models of early diagenetic processes: The muddy seafloor as an unsteady, batch reactor. J. Mar. Res. 62, 815-835. doi:10.1357/0022240042880837

Aller, R.C., 1980. Diagenetic Processes Near the Sediment-Water Interface of Long Island Sound. Ii. Fe and Mn, in: Adv. Geophys.; (United States).

Aller, R.C., Blair, N.E., 2006. Carbon remineralization in the Amazon-Guianas tropical mobile mudbelt: A sedimentary incinerator. Cont. Shelf Res., Special Issue in Honor of Richard W. Sternberg's Contributions to Marine Sedimentology 26, 2241-2259. doi:10.1016/j.csr.2006.07.016

Aller, R.C., Heilbrun, C., Panzeca, C., Zhu, Z., Baltzer, F., 2004. Coupling between sedimentary dynamics, early diagenetic processes, and biogeochemical cycling in the Amazon-Guianas mobile mud belt: coastal French Guiana. Mar. Geol. 208, 331-360. doi:10.1016/j.margeo.2004.04.027

Alongi, D., Boyle, S., Tirendi, F., Payn, C., 1996. Composition and behaviour of trace metals in post-oxic sediments of the Gulf of Papua, Papua New Guinea. Estuar. Coast. Shelf Sci. 42, 197-211.

Alperin, M.J., Albert, D.B., Martens, C.S., 1994. Seasonal variations in production and consumption rates of dissolved organic carbon in an organic-rich coastal sediment. Geochim. Cosmochim. Acta 58, 4909-4930.

Andrieux-Loyer, F., Philippon, X., Bally, G., Kérouel, R., Youenou, A., Le Grand, J., 2008. Phosphorus dynamics and bioavailability in sediments of the Penzé Estuary (NW France): in relation to annual P-fluxes and occurrences of Alexandrium Minutum. Biogeochemistry 88, 213-231. doi:10.1007/s10533-008-9199-2

Anschutz, P., Chaillou, G., Lecroart, P., 2007. Phosphorus diagenesis in sediment of the Thau Lagoon. Estuar. Coast. Shelf Sci. 72, 447-456. doi:10.1016/j.ecss.2006.11.012

Anschutz, P., Dedieu, K., Desmazes, F., Chaillou, G., 2005. Speciation, oxidation state, and reactivity of particulate manganese in marine sediments. Chem. Geol. 218, 265-279. doi:10.1016/j.chemgeo.2005.01.008

Anschutz, P., Hyacinthe, C., Carbonel, P., Jouanneau, J.-M., Jorissen, F., 1999. La distribution du phosphore inorganique dans les sédiments modernes du Golfe de Gascogne. Comptes Rendus Acad. Sci.-Ser. IIA-Earth Planet. Sci. 328, 765-771.

Anschutz, P., Zhong, S., Sundby, B., Mucci, A., Gobeil, C., 1998. Burial efficiency of phosphorus and the geochemistry of iron in continental margin sediments. Limnol. Oceanogr. 43, 53-64.

Appleby, P., Oldfield, F., 1992. Applications of lead-210 to sedimentation studies, in: Uranium-Series Disequilibrium: Applications to Earth, Marine, and Environmental Sciences. 2. Ed. 
Audry, S., Blanc, G., Schäfer, J., Chaillou, G., Robert, S., 2006. Early diagenesis of trace metals $(\mathrm{Cd}, \mathrm{Cu}, \mathrm{Co}, \mathrm{Ni}, \mathrm{U}, \mathrm{Mo}$, and $\mathrm{V})$ in the freshwater reaches of a macrotidal estuary. Geochim. Cosmochim. Acta 70, 2264-2282. doi:10.1016/j.gca.2006.02.001

Beck, M., Dellwig, O., Schnetger, B., Brumsack, H.-J., 2008. Cycling of trace metals (Mn, $\mathrm{Fe}, \mathrm{Mo}, \mathrm{U}, \mathrm{V}, \mathrm{Cr}$ ) in deep pore waters of intertidal flat sediments. Geochim. Cosmochim. Acta 72, 2822-2840. doi:10.1016/j.gca.2008.04.013

Benyoucef, I., 2014. Télédétection visible proche-infrarouge de la distribution spatiotemporelle du microphytobenthos estuarien (Ph.D. thesis). Université de Nantes.

Berner, R.A., 1980. Early diagenesis : a theoretical approach. Princeton : Princeton University Press.

Boudreau, B.P., 1997. Diagenetic Models and Their Implementation Modelling Transport and Reactions in Aquatic Sediments. Springer Berlin Heidelberg, Berlin, Heidelberg.

Cathalot, C., Rabouille, C., Pastor, L., Deflandre, B., Viollier, E., Buscail, R., Grémare, A., Treignier, C., Pruski, A., others, 2010. Temporal variability of carbon recycling in coastal sediments influenced by rivers: assessing the impact of flood inputs in the Rhône River prodelta. Biogeosciences 7, 1187-1205.

Clavero, V., Niell, F.X., Fernandez, J.A., 1991. Effects of Nereis diversicolor O. F. Muller abundance on the dissolved phosphate exchange between sediment and overlying water in Palmones River estuary (southern Spain). Estuarine, Coastal and Shelf Science 33, 193-202. doi:10.1016/0272-7714(91)90006-W

Dang, D.H., Lenoble, V., Durrieu, G., Omanović, D., Mullot, J.-U., Mounier, S., Garnier, C., 2015. Seasonal variations of coastal sedimentary trace metals cycling: Insight on the effect of manganese and iron (oxy)hydroxides, sulphide and organic matter. Mar. Pollut. Bull. 92, 113-124. doi:10.1016/j.marpolbul.2014.12.048

Davenport, E.S., Shull, D.H., Devol, A.H., 2012. Roles of sorption and tube-dwelling benthos in the cycling of phosphorus in Bering Sea sediments. Deep Sea Research Part II: Topical Studies in Oceanography, Understanding Ecosystem Processes in the Eastern Bering Sea 65-70, 163-172. doi:10.1016/j.dsr2.2012.02.004

Davison, W., Zhang, H., 1994. In situspeciation measurements of trace components in natural waters using thin-film gels. Nature 367, 546-548. doi:10.1038/367546a0

Deborde, J., Abril, G., Mouret, A., Jézéquel, D., Thouzeau, G., Clavier, J., Bachelet, G., Anschutz, P., 2008. Effects of seasonal dynamics in a Zostera noltii meadow on phosphorus and iron cycles in a tidal mudflat (Arcachon Bay, France). Mar. Ecol. Prog. Ser. 355, 59-71. doi:10.3354/meps07254

Deflandre, B., Mucci, A., Gagné, J.-P., Guignard, C., Sundby, B. jørn, 2002. Early diagenetic processes in coastal marine sediments disturbed by a catastrophic sedimentation event. Geochim. Cosmochim. Acta 66, 2547-2558. doi:10.1016/S0016-7037(02)00861-X

Delgard, M.-L., Deflandre, B., Deborde, J., Richard, M., Charbonnier, C., Anschutz, P., 2013. Changes in nutrient biogeochemistry in response to the regression of Zostera noltii meadows in the Arcachon Bay (France). Aquat. Geochem. 19, 241-259.

Dellwig, O., Bosselmann, K., Kölsch, S., Hentscher, M., Hinrichs, J., Böttcher, M.E., Reuter, R., Brumsack, H.-J., 2007. Sources and fate of manganese in a tidal basin of the German Wadden Sea. J. Sea Res. 57, 1-18. doi:10.1016/j.seares.2006.07.006

Deloffre, J., Lafite, R., Lesueur, P., Verney, R., Lesourd, S., Cuvilliez, A., Taylor, J., 2006. Controlling factors of rhythmic sedimentation processes on an intertidal estuarine mudflat - Role of the turbidity maximum in the macrotidal Seine estuary, France. Mar. Geol. 235, 151-164. doi:10.1016/j.margeo.2006.10.011

DREAL-Pays-de-Loire, 2015. DREAL Pays-de-Loire/ Banque HYDRO MEEDDAT/DGPR/SRNH [WWW Document]. URL http://www.hydro.eaufrance.fr/i 
Duport, E., Stora, G., Tremblay, P., Gilbert, F., 2006. Effects of population density on the sediment mixing induced by the gallery-diffusor Hediste (Nereis) diversicolor O.F. Müller, 1776. J. Exp. Mar. Biol. Ecol. 336, 33-41. doi:10.1016/j.jembe.2006.04.005

ECC, 1991. Council Directive 91/676/EEC Concerning the Protection of Waters Against Pollution Caused by Nitrates from Agricultural Sources.

Ekeroth, N., Lindström, M., Blomqvist, S., Hall, P.O.J., 2012. Recolonisation by Macrobenthos Mobilises Organic Phosphorus from Reoxidised Baltic Sea Sediments. Aquat Geochem 18, 499-513. doi:10.1007/s10498-012-9172-5

Froelich, P.N., Klinkhammer, G.P., Bender, M.L., Luedtke, N.A., Heath, G.R., Cullen, D., Dauphin, P., Hammond, D., Hartman, B., Maynard, V., 1979. Early oxidation of organic matter in pelagic sediments of the eastern equatorial Atlantic: suboxic diagenesis. Geochim. Cosmochim. Acta 43, 1075-1090. doi:10.1016/00167037(79)90095-4

Gneiting, T., Ševčíková, H., Percival, D.B., 2012. Estimators of Fractal Dimension: Assessing the Roughness of Time Series and Spatial Data. Stat. Sci. 27, 247-277. doi:10.1214/11-STS370

Gobeil, C., Macdonald, R.W., Sundby, B., 1997. Diagenetic separation of cadmium and manganese in suboxic continental margin sediments. Geochim. Cosmochim. Acta 61, 4647-4654.

Goubert, E., Frenod, E., Peeters, P., Thuillier, P., Vested, H.J., Bernard, N., 2010. Utilisation de données altimétriques (Altus) dans la caractérisation de climats hydrodynamiques contrôlant le fonctionnement hydrosédimentaire d'une vasière intertidale: cas de l'estuaire de la Vilaine (Bretagne, France). Rev. Paralia 3, 6.1-6.15. doi:10.5150/revue-paralia.2010.006

Hyacinthe, C., Anschutz, P., Carbonel, P., Jouanneau, J.-M., Jorissen, F.J., 2001. Early diagenetic processes in the muddy sediments of the Bay of Biscay. Mar. Geol. 177, 111-128. doi:10.1016/S0025-3227(01)00127-X

Hyacinthe, C., Bonneville, S., Van Cappellen, P., 2006. Reactive iron(III) in sediments: Chemical versus microbial extractions. Geochim. Cosmochim. Acta 70, 4166-4180. doi:10.1016/j.gca.2006.05.018

Jensen, H.S., Thamdrup, B., 1993. Iron-bound phosphorus in marine sediments as measured by bicarbonate-dithionite extraction. Hydrobiologia 253, 47-59. doi:10.1007/BF00050721

Kostka, J.E., Luther, G.W., 1994. Partitioning and speciation of solid phase iron in saltmarsh sediments. Geochim. Cosmochim. Acta 58, 1701-1710. doi:10.1016/00167037(94)90531-2

Kristensen, E., PenhaLopes, G., Delefosse, M., Valdemarsen, T., Quintana, C.O., Banta, G.T., 2012. REVIEW What is bioturbation? The need for a precise definition for fauna in aquatic sciences. Mar. Ecol. Prog. Ser. 446, 285-302. doi:10.3354/meps09506

Krom, M.D., Davison, P., Zhang, H., Davison, W., 1994. High-resolution pore-water sampling with a gel sampler. Limnol. Oceanogr. 39, 1967-1972.

Le Foch, J.-F., 1961. Propagation de la marée dynamique dans l'estuaire de la Seine et la Seine maritime. (Thèse d'Etat). Paris.

Mackin, J.E., Aller, R.C., Ullman, W.J., 1988. The effects of iron reduction and nonsteadystate diagenesis on iodine, ammonium, and boron distributions in sediments from the Amazon continental shelf. Cont. Shelf Res. 8, 363-386.

Magni, P., Montani, S., 2006. Seasonal patterns of pore-water nutrients, benthic chlorophyll a and sedimentary AVS in a macrobenthos-rich tidal flat. Hydrobiologia 571, 297-311. doi:10.1007/s10750-006-0242-9 
Martin, S.T., 2003. Precipitation and dissolution of iron and manganese oxides, in: Environmental Catalysis. Vicki H. Grassian.

McKee, B.A., Aller, R.C., Allison, M.A., Bianchi, T.S., Kineke, G.C., 2004. Transport and transformation of dissolved and particulate materials on continental margins influenced by major rivers: benthic boundary layer and seabed processes. Cont. Shelf Res. 24, 899-926. doi:10.1016/j.csr.2004.02.009

Meiggs, D., Taillefert, M., 2011. The effect of riverine discharge on biogeochemical processes in estuarine sediments. Limnol. Oceanogr. 56, 1797-1810. doi:10.4319/lo.2011.56.5.1797

Metzger, E., Viollier, E., Simonucci, C., Prévot, F., Langlet, D., Jézéquel, D., 2013. Millimeter-scale alkalinity measurement in marine sediment using DET probes and colorimetric determination. Water Res. 47, 5575-5583.

Meybeck, M., Cauwet, G., Dessery, S., Somville, M., Gouleau, D., Billen, G., 1988. Nutrients (organic C, P, N, Si) in the eutrophic River Loire (France) and its estuary. Estuar. Coast. Shelf Sci. 27, 595-624. doi:10.1016/0272-7714(88)90071-6

Meysman, F.J.., Burdorf, L., in prep. The estimation of geochemical rates and fluxes in aquatic sediments.

Meysman, F.J.R., Middelburg, J.J., Heip, C.H.R., 2006. Bioturbation: a fresh look at Darwin's last idea. Trends Ecol. Evol. 21, 688-695. doi:10.1016/j.tree.2006.08.002

Millero, F.J., Sotolongo, S., Izaguirre, M., 1987. The oxidation kinetics of Fe(II) in seawater. Geochim. Cosmochim. Acta 51, 793-801. doi:10.1016/0016-7037(87)90093-7

Minaudo, C., Meybeck, M., Moatar, F., Gassama, N., Curie, F., 2015. Eutrophication mitigation in rivers: 30 years of trends in spatial and seasonal patterns of biogeochemistry of the Loire River (1980-2012). Biogeosciences 12, 2549-2563. doi:10.5194/bg-12-2549-2015

Moore, R., Burton, J., Williams, P.L., Young, M., 1979. The behaviour of dissolved organic material, iron and manganese in estuarine mixing. Geochim. Cosmochim. Acta 43, 919-926.

Mort, H.P., Slomp, C.P., Gustafsson, B.G., Andersen, T.J., 2010. Phosphorus recycling and burial in Baltic Sea sediments with contrasting redox conditions. Geochim. Cosmochim. Acta 74, 1350-1362. doi:10.1016/j.gca.2009.11.016

Mortimer, C.H., 1971. Chemical exchanges between sediments and water in the Great Lakesspeculations on probable regulatory mechanisms. Limnol Ocean. 16, 387-404.

Mortimer, R., Davey, J., Krom, M., Watson, P., Frickers, P., Clifton, R., 1999. The effect of macrofauna on porewater profiles and nutrient fluxes in the intertidal zone of the Humber Estuary. Estuar. Coast. Shelf Sci. 48, 683-699.

Mouret, A., Anschutz, P., Deflandre, B., Deborde, J., Canton, M., Poirier, D., Grémare, A., Howa, H., 2016. Spatial heterogeneity of benthic biogeochemistry in two contrasted marine environments (Arcachon Bay and Bay of Biscay, SW France). Estuar. Coast. Shelf Sci. 179, 51-65. doi:10.1016/j.ecss.2015.09.001

Murray, J., Irvine, R., 1895. XXXII.-On the Manganese Oxides and Manganese Nodules in Marine Deposits. Earth Environ. Sci. Trans. R. Soc. Edinb. 37, 721-742. doi:10.1017/S0080456800032816

Neupane, G., Donahoe, R.J., Arai, Y., 2014. Kinetics of competitive adsorption/desorption of arsenate and phosphate at the ferrihydrite-water interface. Chem. Geol. 368, 31-38. doi:10.1016/j.chemgeo.2013.12.020

Pedersen, T.F., Vogel, J.S., Southon, J.R., 1986. Copper and manganese in hemipelagic sediments at $21 \mathrm{~N}$, East Pacific Rise: Diagenetic contrasts. Geochim. Cosmochim. Acta 50, 2019-2031. 
Podda, F., Michard, G., 1994. Mesure colorimétrique de l'alcalinité. Comptes Rendus Académie Sci. Sér. 2 Sci. Terre Planètes 319, 651-657.

Poulton, S.W., Raiswell, R., 2002. The low-temperature geochemical cycle of iron: from continental fluxes to marine sediment deposition. Am. J. Sci. 302, 774-805.

Quintana, C.O., Tang, M., Kristensen, E., 2007. Simultaneous study of particle reworking, irrigation transport and reaction rates in sediment bioturbated by the polychaetes Heteromastus and Marenzelleria. J. Exp. Mar. Biol. Ecol. 352, 392-406. doi:10.1016/j.jembe.2007.08.015

Raiswell, R., 2011. Iron Transport from the Continents to the Open Ocean: The AgingRejuvenation Cycle. Elements 7, 101-106. doi:10.2113/gselements.7.2.101

Raiswell, R., Vu, H.P., Brinza, L., Benning, L.G., 2010. The determination of labile Fe in ferrihydrite by ascorbic acid extraction: methodology, dissolution kinetics and loss of solubility with age and de-watering. Chem. Geol. 278, 70-79.

Rehm, E., 1985. The distribution of phosphorus in the Weser river estuary. Environ. Technol. 6, 53-64.

Robbins, J.A., Callender, E., 1975. Diagenesis of manganese in Lake Michigan sediments. Am. J. Sci. 275, 512-533. doi:10.2475/ajs.275.5.512

Robert, S., Blanc, G., Schäfer, J., Lavaux, G., Abril, G., 2004. Metal mobilization in the Gironde Estuary (France): the role of the soft mud layer in the maximum turbidity zone. Mar. Chem. 87, 1-13. doi:10.1016/S0304-4203(03)00088-4

Roy, M., McManus, J., Goñi, M.A., Chase, Z., Borgeld, J.C., Wheatcroft, R.A., Muratli, J.M., Megowan, M.R., Mix, A., 2013. Reactive iron and manganese distributions in seabed sediments near small mountainous rivers off Oregon and California (USA). Cont. Shelf Res. 54, 67-79. doi:10.1016/j.csr.2012.12.012

Rozan, T.F., Taillefert, M., Trouwborst, R.E., Glazer, B.T., Ma, S., Herszage, J., Valdes, L.M., Price, K.S., Luther, G.W., 2002. Iron-sulfur-phosphorus cycling in the sediments of a shallow coastal bay: Implications for sediment nutrient release and benthic macroalgal blooms. Limnol. Oceanogr. 47, 1346-1354.

Sarazin, G., Michard, G., Prevot, F., 1999. A rapid and accurate spectroscopic method for alkalinity measurements in sea water samples. Water Res. 33, 290-294. doi:10.1016/S0043-1354(98)00168-7

Savitzky, A., Golay, M.J.E., 1964. Smoothing and Differentiation of Data by Simplified Least Squares Procedures. Anal. Chem. 36, 1627-1639. doi:10.1021/ac60214a047

Slomp, C., Van der Gaast, S., Van Raaphorst, W., 1996. Phosphorus binding by poorly crystalline iron oxides in North Sea sediments. Mar. Chem. 52, 55-73.

Sundby, B., 2006. Transient state diagenesis in continental margin muds. Mar. Chem. 102, 212. doi:10.1016/j.marchem.2005.09.016

Sundby, B., Gobeil, C., Silverberg, N., Mucci, A., 1992. The phosphorus cycle in coastal marine sediments. Limnol Ocean. 37.

Sundby, B., Silverberg, N., 1985. Manganese fluxes in the benthic boundary layer. Limnol. Oceanogr. 30, 372-381. doi:10.4319/lo.1985.30.2.0372

Thamdrup, B., Fossing, H., Jørgensen, B.B., 1994. Manganese, iron and sulfur cycling in a coastal marine sediment, Aarhus bay, Denmark. Geochim. Cosmochim. Acta 58, 5115-5129. doi:10.1016/0016-7037(94)90298-4

Thibault de Chanvalon, A., Metzger, E., Mouret, A., Cesbron, F., Knoery, J., Rozuel, E., Launeau, P., Nardelli, M.P., Jorissen, F.J., Geslin, E., 2015. Two-dimensional distribution of living benthic foraminifera in anoxic sediment layers of an estuarine mudflat (Loire estuary, France). Biogeosciences 12, 6219-6234. doi:10.5194/bg-126219-2015 
Thibault de Chanvalon, A., Metzger, E., Mouret, A., Geslin, E., Knoery, J., Meysman, F.J.R., in press. Two dimensional mapping of iron release in marine sediments at submillimetre scale. Mar. Chem. doi:10.1016/j.marchem.2016.04.003

Trefry, J.H., Presley, B.J., 1982. Manganese fluxes from Mississippi Delta sediments. Geochim. Cosmochim. Acta 46, 1715-1726. doi:10.1016/0016-7037(82)90112-0

Turner, L.J., Delorme, L.D., 1996. Assessment of $210 \mathrm{~Pb}$ data from Canadian lakes using the CIC and CRS models. Environ. Geol. 28, 78-87.

van der Zee, C., Slomp, C.P., van Raaphorst, W., 2002. Authigenic P formation and reactive P burial in sediments of the Nazare canyon on the Iberian margin (NE Atlantic). Mar. Geol. 185, 379-392.

Wang, Y., Van Cappellen, P., 1996. A multicomponent reactive transport model of early diagenesis: Application to redox cycling in coastal marine sediments. Geochim. Cosmochim. Acta 60, 2993-3014. 


\section{Table caption}

Table 1: Stocks of reactive oxides calculated from ascorbate extractions according to equation 2.

Table 2: Apparent production rate (APR) calculated from the production estimated by Savitzky Golay Filter procedure summed over the whole available profile of $[\mathrm{Mn}]_{\mathrm{d}}$ and $[\mathrm{Fe}]_{\mathrm{d}}$.

Table 3: ranges of $\mathrm{P} / \mathrm{Fe}$ ratios obtained by ascorbate extraction and dithionite extraction of sediments from cores sampled in different coastal environments. When available mean $\mathrm{P} / \mathrm{Fe}$ ratio is specified in italic. ${ }^{a}$ Anschutz et al. (1998) ${ }^{b}$ Anschutz et al. (2007) ${ }^{c}$ Rozan et al. (2002) ${ }^{\text {d }}$ Deborde et al. (2008) ${ }^{\text {e }}$ Delgard et al. (2013) ${ }^{\mathrm{f}}$ Mouret et al. (2015) ${ }^{\mathrm{g}}$ Anschutz et al. (1999) ${ }^{\mathrm{h}}$ Mort et al. (2010) ${ }^{\mathrm{i}}$ Jensen and Thamdrup (1993) ${ }^{\mathrm{j}}$ Sundby et al. (1992) ${ }^{\mathrm{k}}$ Slomp et al. (1996) ${ }^{1}$ van der Zee (2002) ${ }^{\mathrm{m}}$ Andrieux-Loyer et al. (2008). 


\section{Figure caption}

Figure 1: Location of the two sampling sites.

Figure 2: Water discharge from January 2012 to December 2015. The black line represents daily flow, dotted and grey lines represent median discharge and 20 and 80 percentile of the monthly flow. Arrows indicate sampling field work periods; triangles the last flood event before each field work and diamonds the last wind event that is characterized by gusts above $70 \mathrm{~km} \mathrm{~h}^{-1}$

Figure 3: Examples of modelled concentrations (black lines) superimposed with original data sets (open circles) and corresponding production rates (red lines; negative production corresponds to consumption) based on Savitsky-Golay Filter procedure (February, site 1, n = 5). Upper boundary condition is set as zero production rate. $\mathrm{P}$ has similar pattern than $\mathrm{Fe}$ and is not shown.

Figure 4: Total organic carbon, porosity and examples of alkalinity profiles for September 2012 (yellow). May 2013 (green) and February 2014 (blue). Results of ${ }^{210} \mathrm{~Pb}_{\mathrm{xs}}$ are only available for Site 1, February 2014. The dotted line represents the maximum raw sedimentation rate of $0.16 \mathrm{~cm} \mathrm{yr}^{-1}$.

Figure 5: Ascorbate-extracted and dissolved manganese, iron and phosphorus from February 2014 (blue), April 2015 ( $\mathrm{t}_{3}$; magenta), May 2013 (green) and September 2012 (yellow). Only one dissolved profile is shown for each situation, the second is similar. There is no data for site 2 in April 2015.

Figure 6: Ascorbate-extracted and dissolved manganese, iron and phosphorus over a one month time series at site $1: t_{0}$ corresponds to black diamonds (available only for dissolved species), $\mathrm{t}_{1}$ to greys, $\mathrm{t}_{2}$ to whites and $\mathrm{t}_{3}$ to magenta diamonds. 
Figure 7: Idealised evolution of Mn (open diamonds) and Fe (black diamonds) at site 1. Time since the deposition event is calculated from the last flood (Fig. 2). Top: Reactive stocks (ascorbate extracted minus background concentration), error bars represent relative standard deviation of background concentrations. Bottom: Apparent production rates estimated from SGF procedure, error bars are standard deviations taking into account 2 replicates and \pm 1 on the smoothing parameter $n$.

Figure 8: (a) Ascorbate extracted $\mathrm{P}$ versus Fe for the whole dataset (only $\mathrm{t}_{3}$ from April), (b) $[\mathrm{P}]_{\text {asc }} /[\mathrm{Fe}]_{\text {asc }}$ according to depth (site 1 only), (c) pore water concentration of $\mathrm{P}$ versus $\mathrm{Fe}$ (data with concentrations below $50 \mu \mathrm{mol} \mathrm{L} \mathrm{L}^{-1}$ are omitted). 


\section{Tables}

Table 1

\begin{tabular}{lcccc}
\hline \multicolumn{5}{c}{ Stocks of reactive oxides $\left(\mathrm{mmol} \mathrm{m}^{-2}\right)$} \\
\cline { 2 - 5 } & $\mathrm{Fe}$ & $\mathrm{Mn}$ & $\mathrm{Fe}$ & $\mathrm{Site} 2$ \\
\hline Feb & 2162 & 448 & 1460 & 306 \\
Aprilt $_{1}$ & 771 & 287 & no data & no data \\
April $_{2}$ & 665 & 221 & no data & no data \\
April $_{3}$ & 1132 & 255 & no data & no data \\
May & 670 & 181 & 251 & 128 \\
Sept & 272 & 106 & 222 & 96 \\
\hline
\end{tabular}

Table 2

\begin{tabular}{|c|c|c|c|c|}
\hline \multicolumn{5}{|c|}{$\operatorname{APR}\left(\mathrm{mmol} \mathrm{m}^{-2} \mathrm{~d}^{-1}\right)$} \\
\hline & \multicolumn{2}{|c|}{ Site 1} & \multicolumn{2}{|c|}{ Site 2} \\
\hline & $\mathrm{Fe}$ & $\mathrm{Mn}$ & $\mathrm{Fe}$ & $\mathrm{Mn}$ \\
\hline$\overline{F e b}$ & $0.58 \pm 0.10$ & $0.11 \pm 0.01$ & $0.19 \pm 0.13$ & $0.01 \pm 0.01$ \\
\hline Aprilt $_{0}$ & $0.00 \pm 0.00$ & $0.02 \pm 0.00$ & no data & no data \\
\hline Aprilt $_{1}$ & $0.21 \pm 0.04$ & $0.75 \pm 0.23$ & no data & no data \\
\hline Aprilt $_{2}$ & $1.22 \pm 0.53$ & $1.43 \pm 0.58$ & no data & no data \\
\hline Aprilt $_{3}$ & $0.41 \pm 0.09$ & $1.20 \pm 0.36$ & no data & no data \\
\hline May & $1.16 \pm 0.65$ & $0.22 \pm 0.08$ & $0.28 \pm 0.09$ & $0.15 \pm 0.05$ \\
\hline Sept & $1.76 \pm 1.15$ & $0.18 \pm 0.12$ & $0.19 \pm 0.06$ & $0.03 \pm 0.01$ \\
\hline
\end{tabular}




\section{Table 3}

\begin{tabular}{|c|c|c|c|c|}
\hline & \multicolumn{2}{|c|}{$[\mathrm{P}]_{\mathrm{asc}} /[\mathrm{Fe}]_{\mathrm{asc}}$} & \multicolumn{2}{|c|}{$[\mathrm{P}]_{\mathrm{dith}} /[\mathrm{Fe}]_{\mathrm{dith}}$} \\
\hline Eastern Canadian continental margin & $0.06-0.41^{a}$ & $0.17 a$ & $0.01-0.07 a$ & $0.03^{a}$ \\
\hline Portuguese continental slope & $0.07-0.22^{a}$ & $0.13^{a}$ & & \\
\hline Chesapeake Bay & $0.01-0.07 a$ & a & & \\
\hline Mediterranean lagoon & $0.07-0.2^{b}$ & & & \\
\hline Rehoboth Bay & $0.04-0.12^{c}$ & & & \\
\hline Arcachon Bay & $0.03-0.09 \mathrm{~d}, \mathrm{e}, \mathrm{f}$ & . & & \\
\hline Bay of Biscay slope & 0.12 & $0.23 f, g$ & & \\
\hline Baltic sea & 0.1 & & $0.06-0.125^{i}$ & \\
\hline Gulf of St Lawrence & & & $0.1 \mathrm{j}$ & \\
\hline North Sea & & & $0.05-0.15^{k}$ & \\
\hline Iberian margin & & & $0.05-0.1$ & \\
\hline Penzé Estuary & & & $0.08-0.25 \mathrm{~m}$ & \\
\hline
\end{tabular}




\section{Figures}

Figure 1

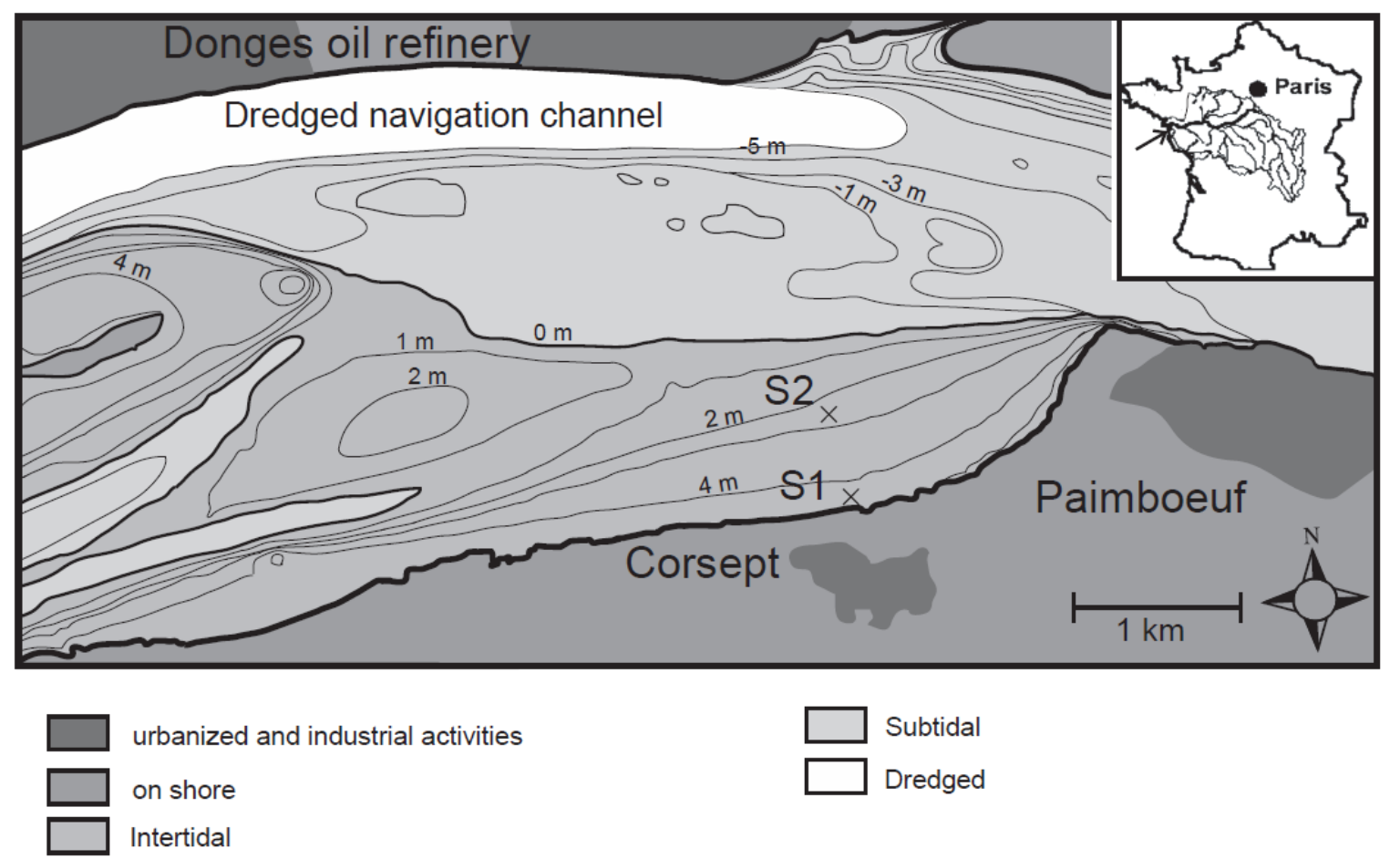


Figure 2

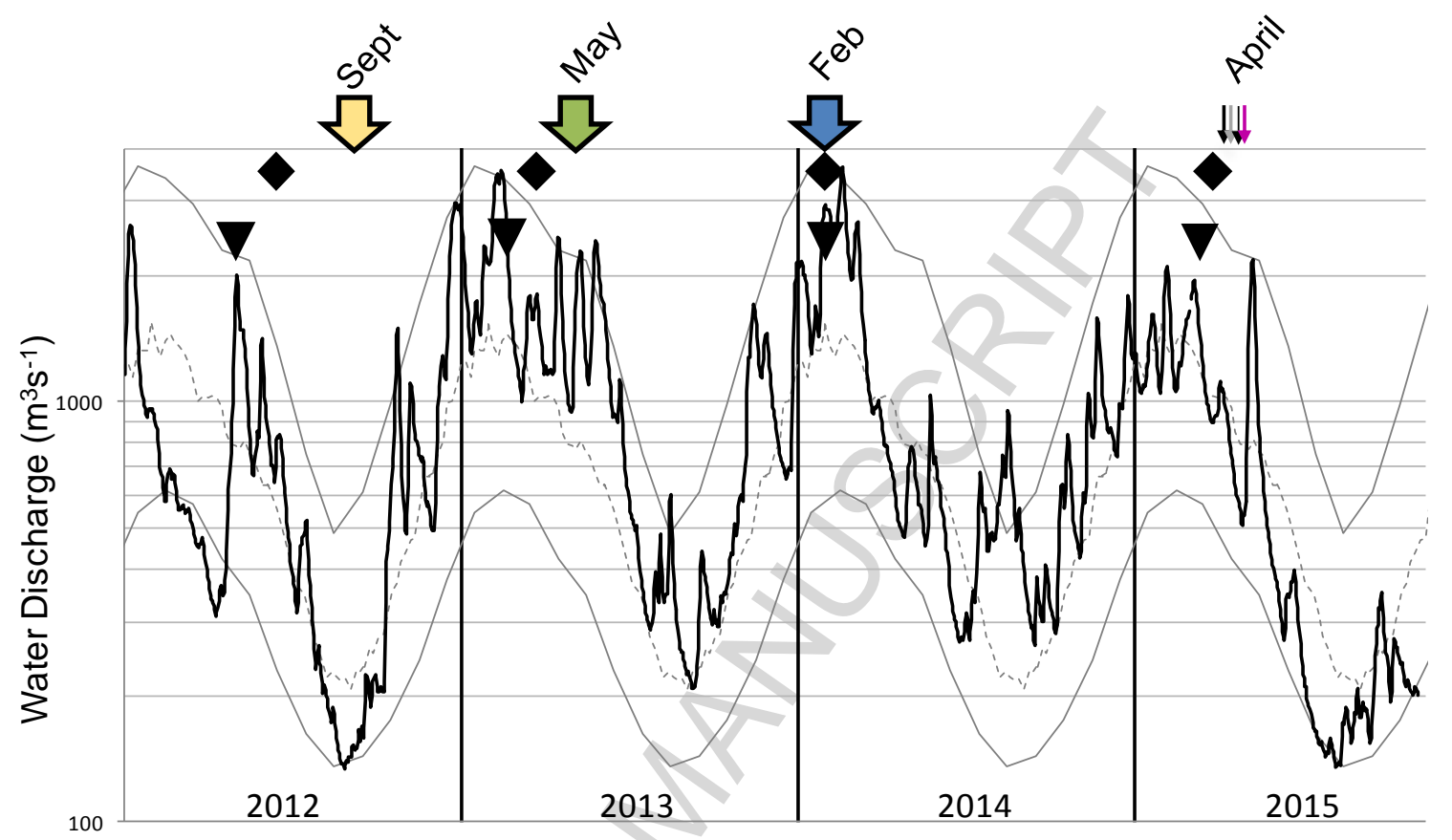


Figure 3
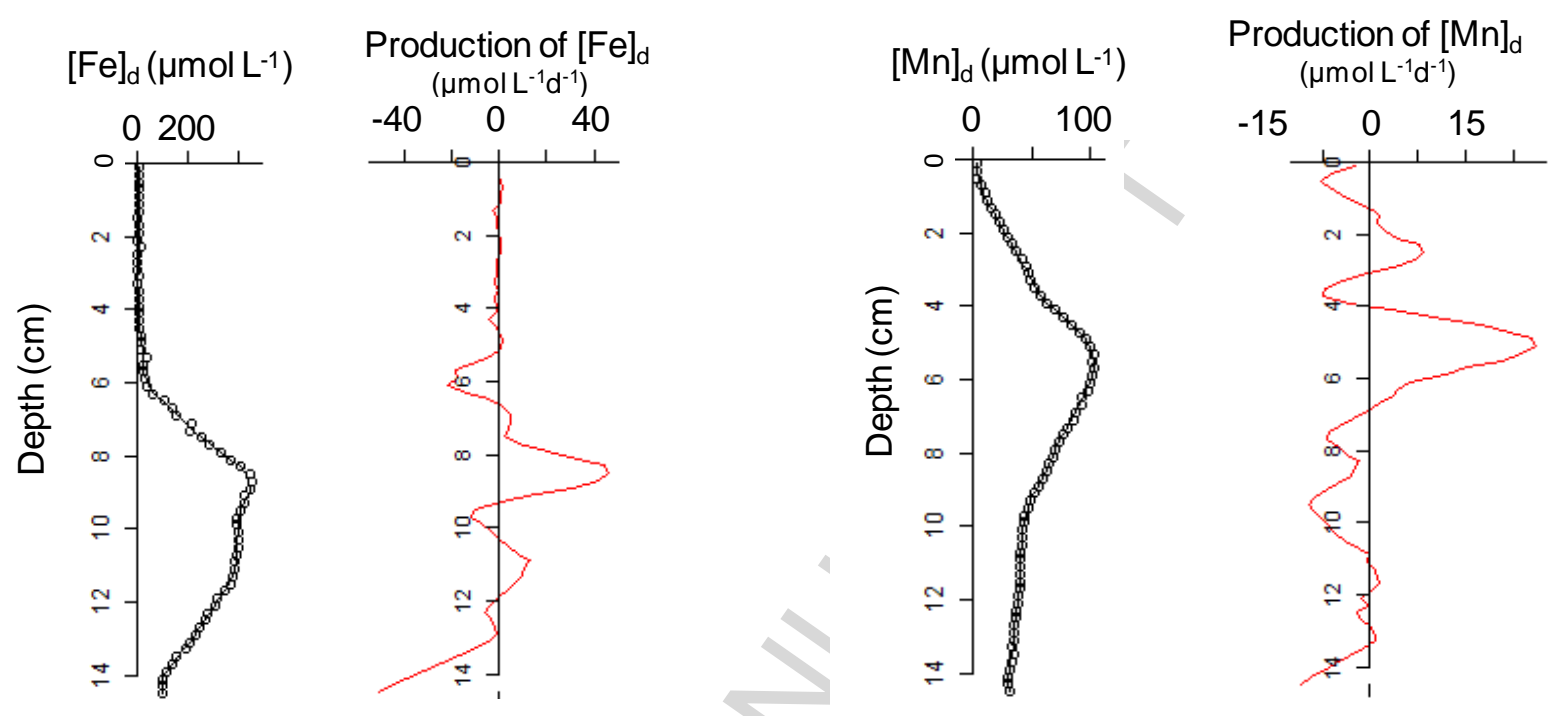
Figure 4
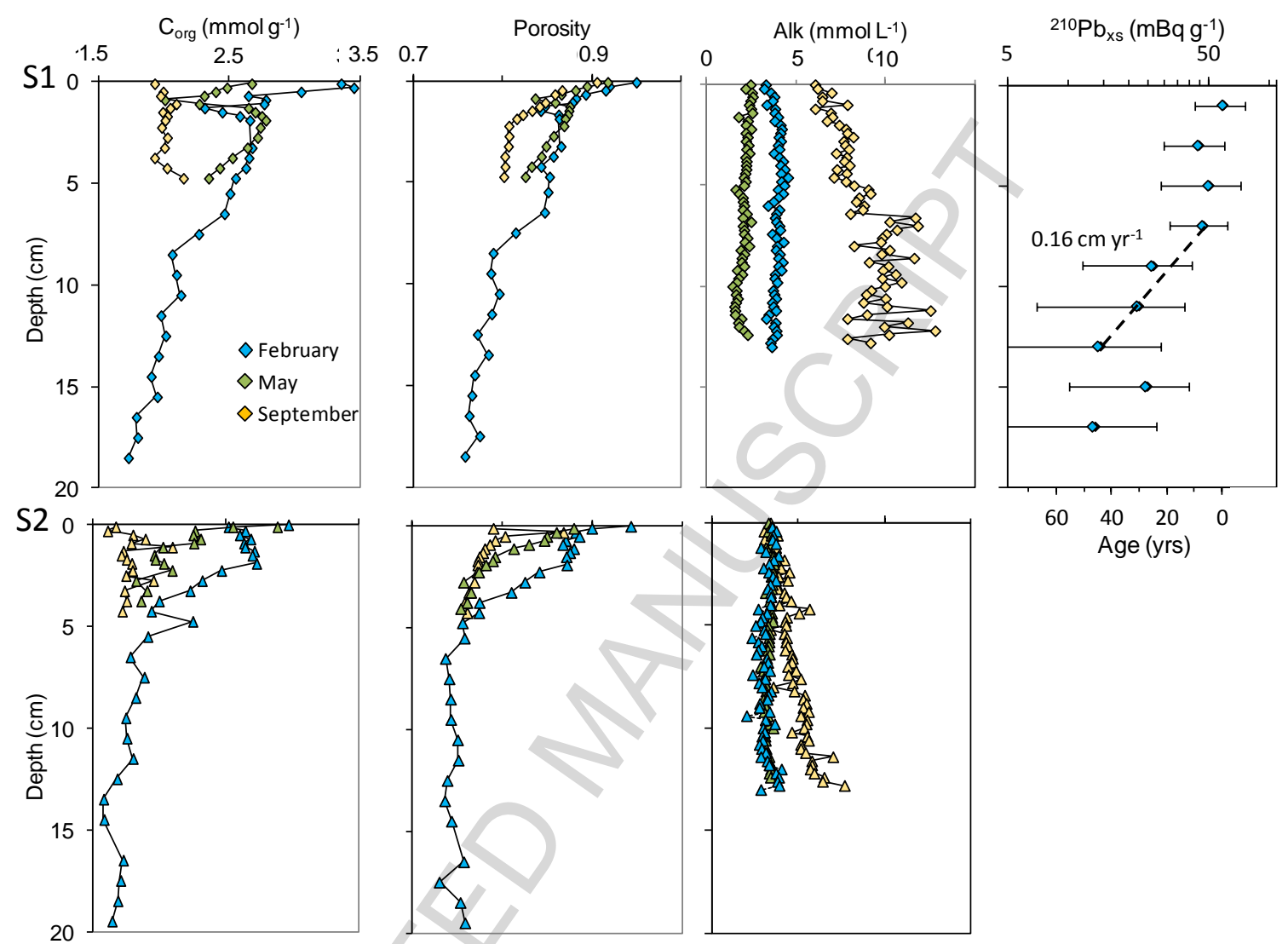
Figure 5

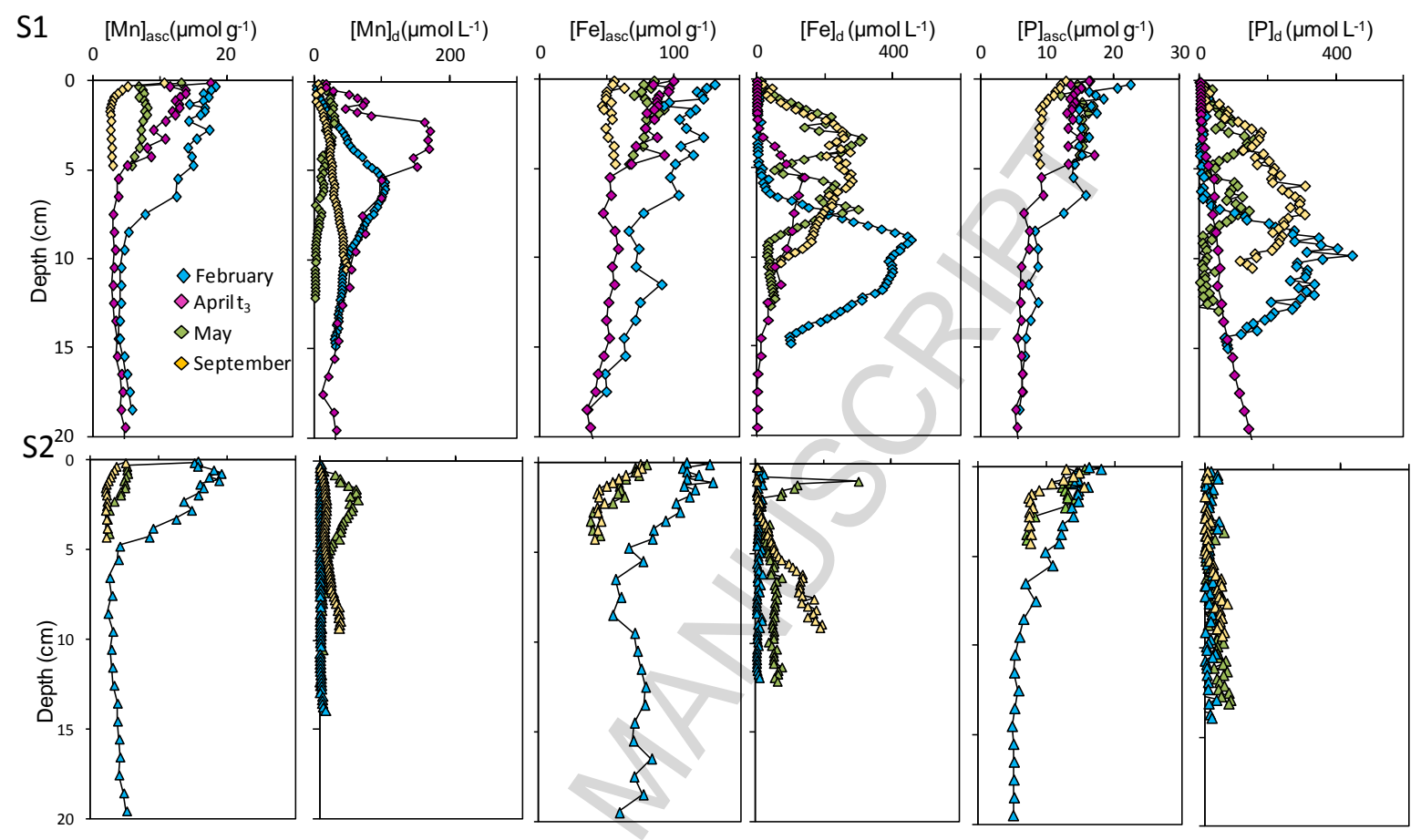


Figure 6

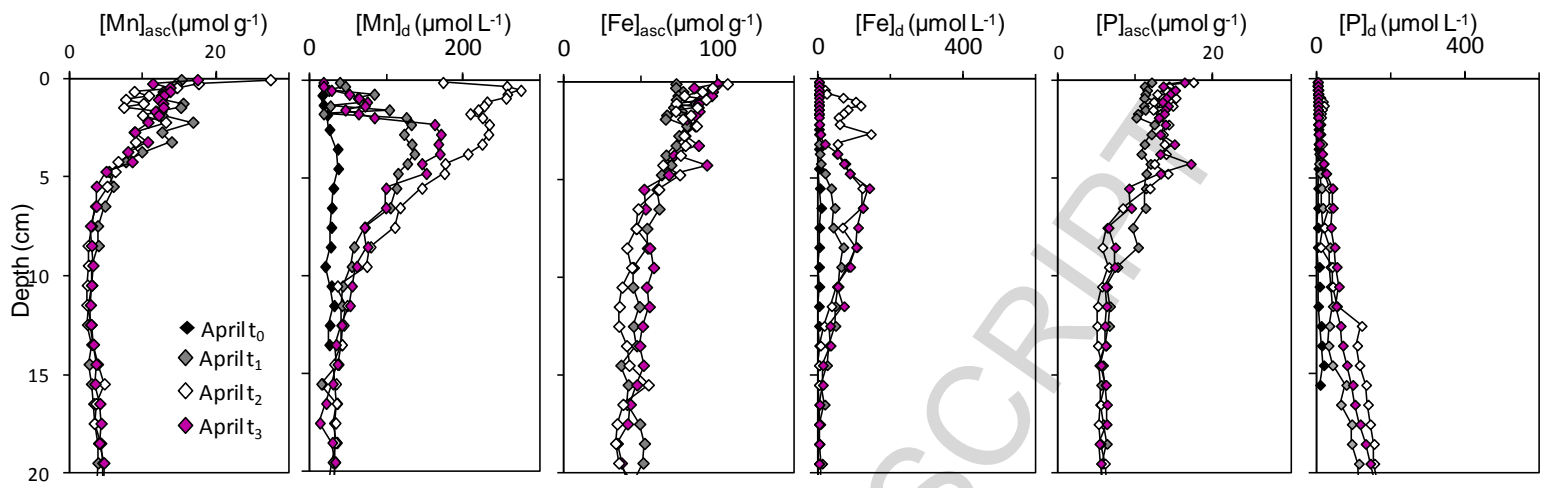


Figure 7
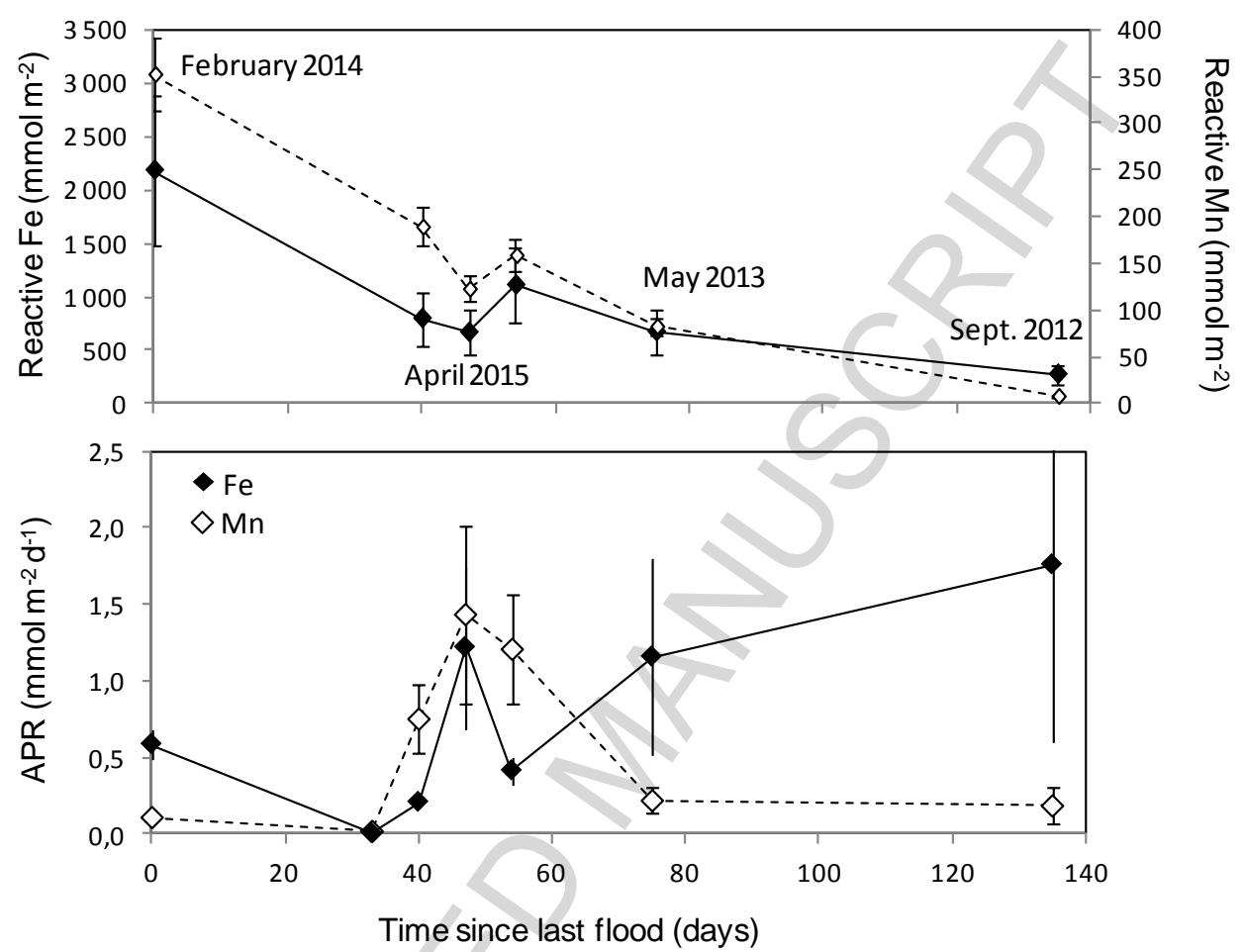
Figure 8
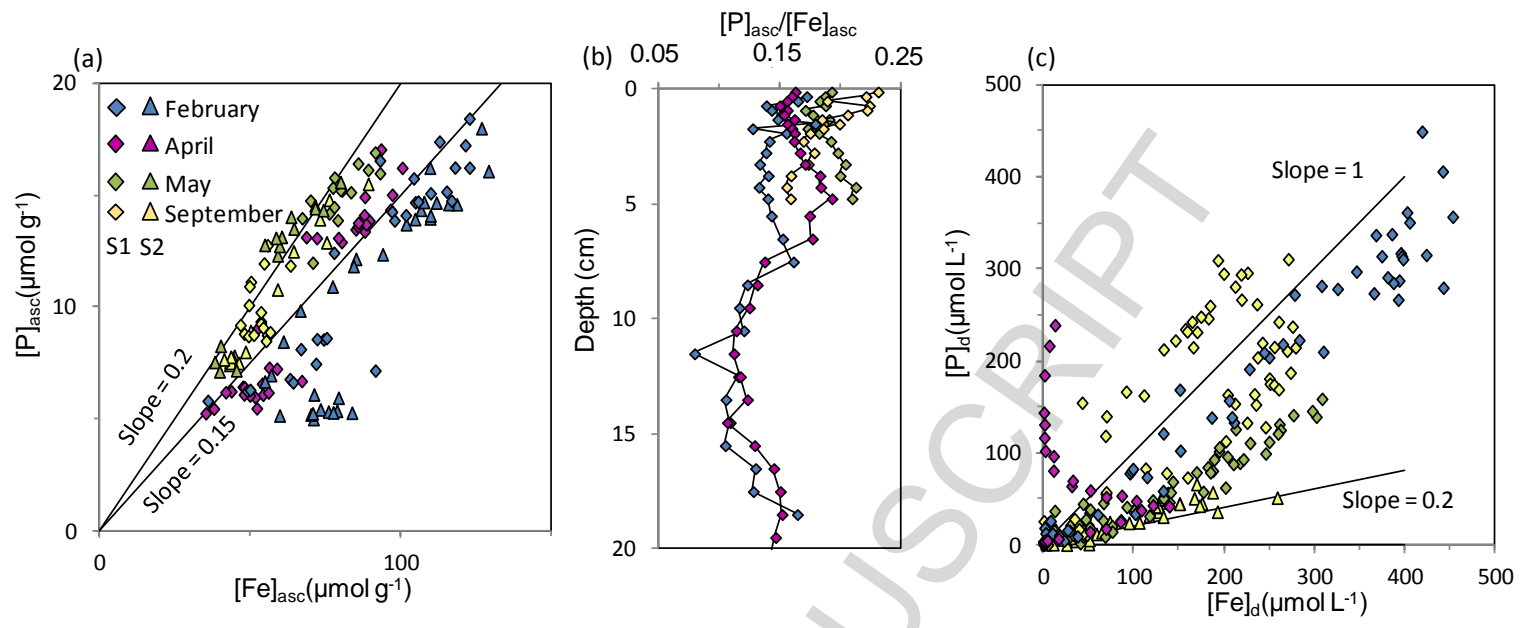